UNIVERSIDADE DE SÃO PAULO

FACULDADE DE ADMINISTRAÇÃO, ECONOMIA E CONTABILIDADE DEPARTAMENTO DE ECONOMIA

PROGRAMA DE PÓS-GRADUAÇÃO EM ECONOMIA

CRÉDITO RURAL E PRODUTO AGROPECUÁRIO MUNICIPAL:

UMA ANÁLISE DE CAUSALIDADE

Isabel Machado Cavalcanti

Orientador: Prof. Dr. Márcio Issao Nakane

SÃO PAULO

2008 


\author{
Prof ${ }^{a}$. Dra . Suely Vilela \\ Reitora da Universidade de São Paulo
}

Prof. Dr. Carlos Roberto Azzoni

Diretor da Faculdade de Economia, Administração e Contabilidade

Prof. Dr. Joaquim José Martins Guilhoto

Chefe do Departamento de Economia

Prof. Dr. Dante Mendes Aldrighi

Coordenador do Programa de Pós-Graduação em Economia 
ISABEL MACHADO CAVALCANTI

\section{CRÉDITO RURAL E PRODUTO AGROPECUÁRIO MUNICIPAL: UMA ANÁLISE DE CAUSALIDADE}

Dissertação apresentada ao Departamento de Economia da Faculdade de Economia, Administração e Contabilidade da Universidade de São Paulo como requisito pra obtenção do título de Mestre em Economia

Orientador: Prof. Dr. Márcio Issao Nakane

\section{SÃO PAULO}




\section{FICHA CATALOGRÁFICA}

Elaborada pela Seção de Processamento Técnico do SBD/FEA/USP

\section{Cavalcanti, Isabel Machado}

Crédito rural e produto agropecuário municipal: uma análise da causalidade / Isabel Machado Cavalcanti. -São Paulo, 2008.

$73 \mathrm{p}$.

Dissertação (Mestrado) - Universidade de São Paulo, 2008 Bibliografia

1. Crédito rural 2. Causalidade 3. Desenvolvimento rural I. Universidade de São Paulo. Faculdade de Economia, Administração e Contabilidade. II. Título. 


\section{AGRADECIMENTOS}

Em primeiro lugar, agradeço ao Prof. Márcio Issao Nakane, por ter aceitado me orientar e por ter dedicado atenção e cuidados a este trabalho. Obrigada pelos apontamentos sempre relevantes e pela valiosa orientação que me permitiram concluir esta dissertação.

Aos integrantes da banca de qualificação, Profs. Eduardo Haddad e Carlos Eduardo Gonçalves, pelas críticas e sugestões, que procurei incorporar à versão final deste trabalho.

Aos colegas da pós-graduação, especialmente à turma de 2006, que tornou mais suave e acolhedora a mudança de cidade e menos árdua e solitária a tarefa de aprender. Em especial, agradeço ao Everton, pela amizade e recepção.

À Marina, que acrescentou alegria e graça aos meus dias em São Paulo e com quem dividi, de perto, uma fase inesquecível da minha vida. Obrigada pela saudável convivência, pelo bom humor e otimismo. Foram indispensáveis nesses dois anos.

Ao Bruno, companhia Leal, que me acompanhou em todas as horas. Sua paciência, amor e carinho formam o apoio emocional essencial em minha vida. Espero agora poder retribuir e recompensar.

À minha família, pai, mãe e irmão, que sempre me apoiaram em todo momento de aflição, sempre deram ouvidos a qualquer chamado meu e sempre se dispuseram a enfrentar qualquer tarefa que fosse, desde que fosse para o meu bem. Aos meus avós, pelo carinho e torcida.

Por fim, agradeço ao CNPQ e à FIPE pelo auxílio financeiro que me proporcionou o privilégio de estudar na FEA / USP. 


\section{RESUMO}

O objetivo deste trabalho é estudar a relação de causalidade entre crédito rural e produto agropecuário. Utilizando dados municipais do período 1999-2004, aplicou-se a metodologia de Granger e Huang (1997), que permite identificar o sentido da causalidade entre duas variáveis em um contexto de painel. Contrariamente à grande parte da literatura que estudou as relações de causalidade entre sistema financeiro e crescimento econômico, este trabalho não identificou a causalidade partindo da variável financeira para o produto. Em geral, os resultados apontaram causalidade unidirecional, partindo do Produto Interno Bruto da agropecuária para o crédito rural. 


\section{ABSTRACT}

The main goal of this essay is to evaluate the causal relations between rural credit and agricultural output. Using municipal data for the period 1999-2004, we have implemented the Granger and Huang (1997) methodology, which allows us to identify the causality direction between two variables in a data panel context. Differently from a large part of the literature that has studied causal relations between finance and growth, this work did not find causality from the financial variable towards output. Instead, the results draw attention to unidirectional causality from agricultural output to rural credit. 



\section{SUMÁRIO}

LISTA DE TABELAS

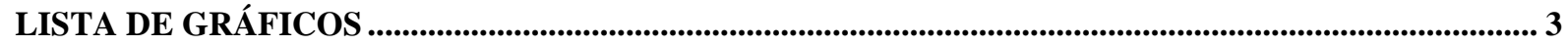

INTRODUÇÃ

1. FUNDAMENTANDO A QUESTÃO: SISTEMA FINANCEIRO E CRESCIMENTO ECONÔMICO... 7

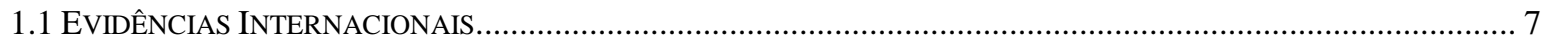

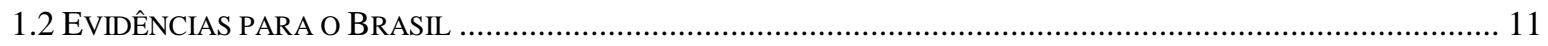

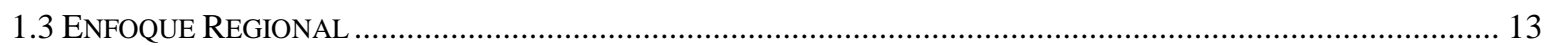

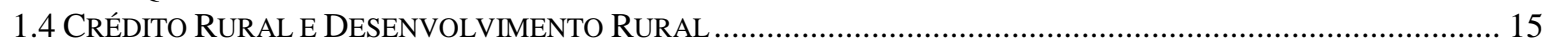

2. DIRECIONANDO A QUESTÃO: SISTEMAS FINANCEIROS RURAIS ............................................... 20

2.1 DESCRIÇÃO DO MERCADO DE CRÉDITO BRASILEIRO EM UMA PERSPECTIVA REGIONAL................................... 20

2.2 JUSTIFICATIVAS PARA A INTERVENÇÃO GOVERNAMENTAL NO MERCADO DE CRÉDITO RURAL .................... 29

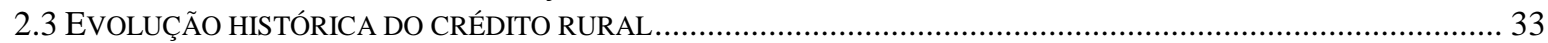



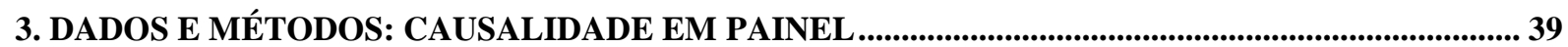



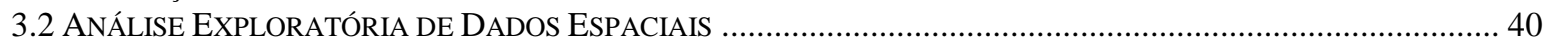

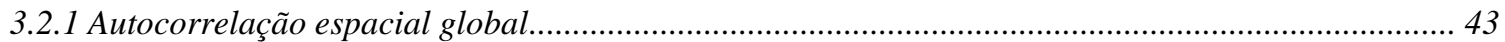

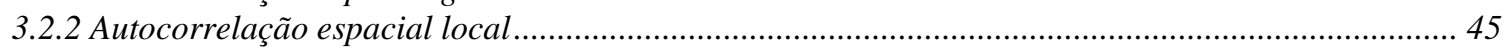

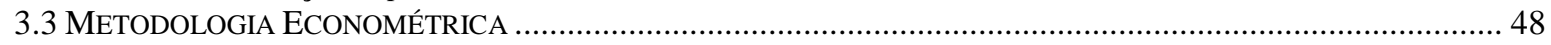

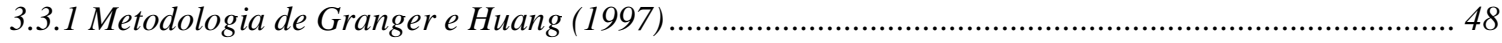

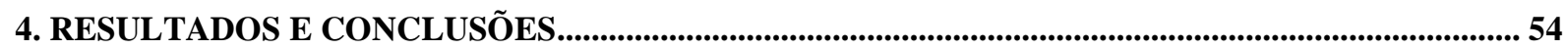

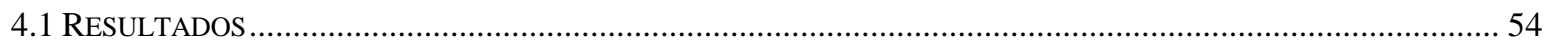



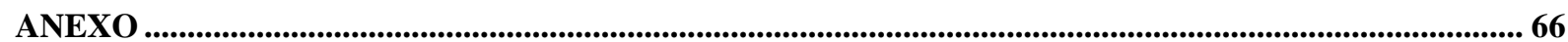




\section{LISTA DE TABELAS}

TABELA 1 - PIB E SERVIÇOS FINANCEIROS: PARTICIPAÇÃO DOS ESTADOS E REGIÕES NO TOTAL DO PAÍS (\%) ........ 23

TABELA 2 - CRÉDITO COM RECURSOS LIVRES E DIRECIONADOS COMO PROPORÇÃO DO CRÉDITO TOTAL (\%) ..........24

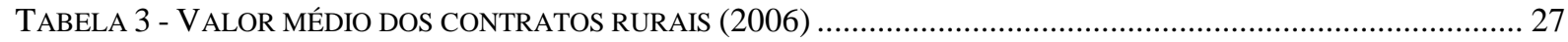

TABELA 4 - FINANCIAMENTOS CONCEDIDOS A PRODUTORES E COOPERATIVAS: POR TIPO DE INSTITUIÇÃO (\%) ..... 28

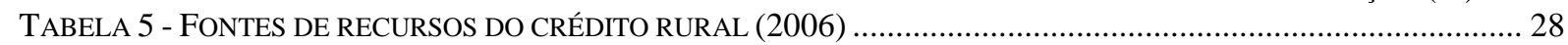

TABELA 6 - PROGRAMAS AgROPECUÁRIOS DO GOVERNO FEDERAL ADMINISTRADOS PELO BNDES ..................... 36

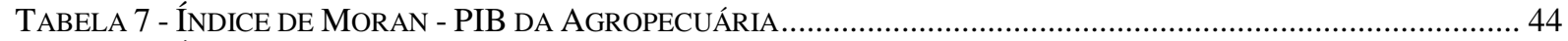



TABELA 9 - RESULTADO DO TESTE SOMA-DIFERENÇA PARA OS MODELOS I E II ..................................................5

TABELA 10 - RESULTADO DO TESTE SOMA-DIFERENÇA PARA OS MODELOS III E IV ….................................... 56

TABELA 11 - RESULTADO DO TESTE SOMA-DIFERENÇA POR REGIÃO GEOGRÁFICA.........................................5 57

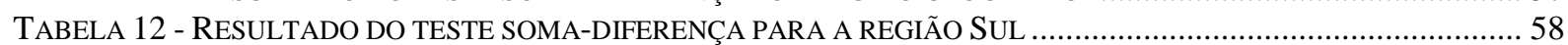




\section{LISTA DE GRÁFICOS}

GRÁFICO 1 - CRÉDITO TOTAL DO SISTEMA FINANCEIRO COMO PROPORÇÃO DO PIB (\%) ...................................... 21

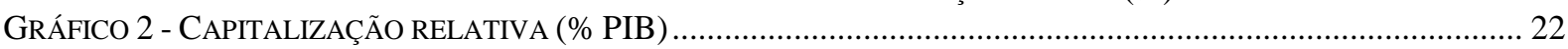

GRÁFICO 3 - CRÉDITO RURAL: EVOLUÇÃO DOS RECURSOS (VALORES CONSTANTES DE 2006*) ............................24

GRÁFICO 4 - CRÉDITO RURAL: ATIVIDADE E FINALIDADE (2006) …...........................................................25

GRÁFICO 5 - VALOR DOS FINANCIAMENTOS CONCEDIDOS (2006) - PARTICIPAÇÃO DAS REGIÕES (\%) ....................25

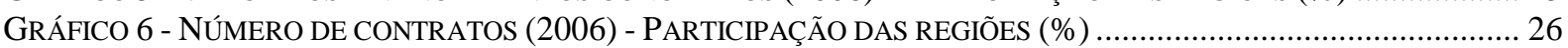

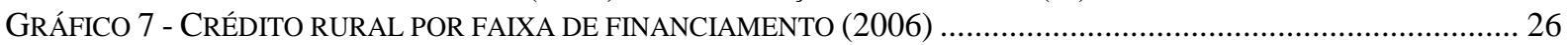

GRÁFICO 8 - EVOLUÇÃO ANUAL DA BALANÇA COMERCIAL BRASILEIRA E DO AGRONEGÓCIO (US\$ BILHÕES) ........ 31

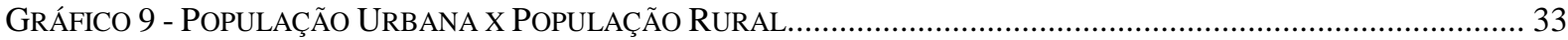

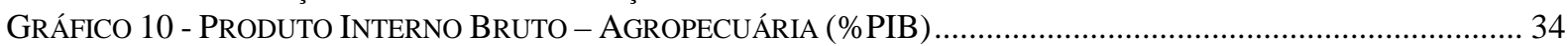




\section{Introdução}

Já é freqüente na literatura a presença de variáveis financeiras como elementos determinantes do crescimento econômico. Grande parte dos trabalhos que contemplam as relações entre sistema financeiro e crescimento econômico, mesmo utilizando os mais variados dados e métodos, aponta para uma correlação positiva entre estas duas variáveis, com a causalidade partindo do sistema financeiro ${ }^{1}$.

A justificativa teórica para este resultado encontra-se nas premissas apresentadas por Levine (1997). O sistema financeiro, ao reduzir os custos de transação e informação e desempenhar suas funções de levantamento de fundos, amenização de riscos, seleção de clientes e direcionamento de recursos para os projetos mais rentáveis, produz maior eficiência alocativa, acumulação de capital, inovação tecnológica e, em última instância, crescimento econômico.

Ocorre que há alguns tipos de crédito ou instrumentos financeiros que sofrem maior intervenção governamental. Nesse caso, podem estar sendo distorcidas as funções básicas do sistema financeiro, fazendo com que este não seja capaz de cumprir seu papel de impulsionar o crescimento econômico. O crédito rural é um exemplo típico de instrumento financeiro marcado pela presença governamental, que exerce sobre sua oferta direcionamentos explícitos e controles de quantidade e de preço.

O objetivo deste trabalho concentra-se, então, em verificar, especificamente para o crédito rural e no nível da economia municipal, a validade da tese de que crédito causa crescimento econômico. Haja vista a ampla intervenção governamental no mercado de crédito rural, faz-se necessário avaliar se o desempenho da atividade agrícola é realmente precedido pelo suprimento de crédito rural subsidiado. A preocupação básica, que tem inclusive implicações de política econômica, é averiguar se, efetivamente, o crédito rural, da maneira como é concedido no Brasil, tem sido capaz de causar elevação no Produto Interno Bruto do setor agropecuário municipal.

Este trabalho está dividido em quatro capítulos além desta introdução. O primeiro capítulo fundamenta, por meio da revisão da literatura, a relação entre sistema financeiro e desenvolvimento econômico. Esta questão é vista sob a ótica da literatura internacional, dos

\footnotetext{
${ }^{1}$ Quadro com as principais referências bibliográficas está apresentado no Anexo 1.
} 
estudos direcionados ao Brasil, sob o aspecto regional e, por fim, no que diz respeito especificamente ao impacto do sistema financeiro sobre o desenvolvimento das regiões rurais.

O segundo capítulo trata de direcionar o estudo para o sistema financeiro rural, inicialmente apresentando características do sistema financeiro brasileiro como um todo e, em seguida, focalizando a análise sobre o crédito rural: suas características, distribuição regional, a que finalidades se destina, justificativas para a sua existência e sua evolução histórica.

O terceiro capítulo apresenta a metodologia do exercício empírico e os dados utilizados e o capítulo final descreve os principais resultados e conclusões. 


\section{Fundamentando a questão: Sistema Financeiro e Crescimento Econômico}

Este capítulo está dividido em quatro seções e tem como objetivo realizar um levantamento da literatura internacional e doméstica acerca do tema "Sistema Financeiro e Crescimento Econômico". A primeira seção sumariza trabalhos importantes da literatura internacional, trazendo um resumo das conclusões e resultados, tanto teóricos como empíricos, alcançados por estes trabalhos. A segunda parte se limita a analisar trabalhos direcionados ao Brasil, mais especificamente, aqueles que se concentraram na questão da causalidade entre Sistema Financeiro e Crescimento Econômico. A terceira seção traz uma breve síntese da literatura focada nos impactos regionais do sistema financeiro e, por fim, a seção final se debruça sobre o tema "Sistema Financeiro e Crescimento Econômico" quando este se aplica ao cenário rural. Pretende-se aqui, tão somente, apresentar o pano de fundo para as indagações realizadas nos capítulos seguintes.

\subsection{Evidências Internacionais}

O tema crescimento econômico é contemplado por uma literatura vasta e rica em modelos que buscam encontrar os fatores que geram o crescimento da renda nacional. Os diversos modelos diferem em termos da escolha das variáveis entendidas como principais propulsoras do crescimento. Os trabalhos clássicos de Solow (1956), Romer (1986) e Lucas (1988) têm como base de sua teoria, variáveis reais como acumulação de capital, variações tecnológicas e capital humano. No que se refere às variáveis financeiras, como a oferta de moeda, o desenvolvimento financeiro e a disponibilidade de crédito, não é consensual sua importância como determinantes do crescimento, embora outros estudos tenham reforçado o papel relevante do lado financeiro em afetar positivamente a dinâmica da atividade econômica.

Desde Schumpeter (1912), o crédito e o desenvolvimento financeiro têm sido apontados como elementos capazes de impactar diretamente o crescimento econômico. Na visão de Schumpeter, a produção requer crédito para que seja materializada e, nesse contexto, os bancos e o setor financeiro têm papel fundamental. O desenvolvimento do setor financeiro é 
capaz de induzir o crescimento econômico pelo fato de permitir maior eficiência na alocação dos recursos financeiros, o que corresponde à maior captação de poupança, aumento de liquidez, transferência de recursos para projetos de maior retorno e acumulação de capital. Todos esses fatores somados levam ao melhoramento do capital físico e humano, à inovação tecnológica e, em última instância, ao crescimento econômico.

Robinson (1952) articula seu argumento na direção contrária, apontando que é o crescimento econômico que precede o desenvolvimento financeiro - "where enterprise leads, finance follows" - e, embora restrições de crédito possam ser uma barreira ao crescimento de países menos desenvolvidos, nos sistemas mais sofisticados o setor financeiro é endógeno e apenas responde aos requerimentos de demanda por serviços financeiros. Sob este ponto de vista, o setor financeiro não teria um papel ativo na promoção do desenvolvimento, mas seria apenas uma resposta às condições econômicas de um país ou região. Lucas (1988) é outro representante cético do papel do desenvolvimento financeiro sobre o crescimento econômico e critica a literatura por "super-enfatizar" a relação de causalidade entre finanças e crescimento.

A relação entre desenvolvimento financeiro e crescimento econômico tem sido tratada tanto teórica como empiricamente. Uma das primeiras tentativas de fornecer um tratamento empírico à questão foi feita por Goldsmith (1969) que examinou dados de 35 países ao longo do período 1860-1963 na tentativa de alcançar basicamente três objetivos: $i$ ) documentar como a estrutura financeira é alterada na medida em que cresce uma economia, ii) estimar o impacto do desenvolvimento financeiro no crescimento econômico e iii) avaliar o quanto a estrutura financeira influencia o ritmo do crescimento econômico. Neste trabalho, foi bem sucedida a documentação da evolução dos intermediários financeiros ao longo dos anos e dos sistemas financeiros nacionais; entretanto, a insuficiência de estatísticas impediu que se delineassem conclusões acabadas sobre as questões empíricas.

King e Levine (1993) estudaram a relação empírica entre crescimento econômico e desenvolvimento do setor financeiro para uma amostra de 80 países de diferentes graus de desenvolvimento no período 1960-1989 e os resultados deste trabalho apontam para uma relação robusta entre nível de desenvolvimento financeiro, crescimento, acumulação de capital físico e eficiência na alocação do capital. Os autores ainda destacam que os resultados empíricos são consistentes com o entendimento de que o sistema financeiro estimula o 
crescimento econômico, já que componentes exógenos dos indicadores financeiros são capazes de prever valores subseqüentes dos indicadores de crescimento.

A visão de que o desenvolvimento financeiro estimula o crescimento econômico justifica-se teoricamente por vários caminhos. Levine (1997) aponta cinco funções básicas do sistema financeiro que levariam ao crescimento por meio de dois canais: acumulação de capital e inovação tecnológica. Em primeiro lugar, o sistema financeiro atua por meio do levantamento de fundos e mobilização de poupança, fatores fundamentais para a viabilização de projetos. Segundo, a amenização dos riscos associados à execução de projetos específicos, assim como redução do risco de liquidez. Terceiro, a redução dos custos de obtenção de informações, o que permite maior eficiência alocativa e difusão mais ampla das oportunidades de investimento. Outra função seria o monitoramento das firmas e governança corporativa, o que reduz os custos de enforcement, aquisição de informações e garantias para o cumprimento dos contratos. Finalmente, o sistema financeiro facilita as trocas através do barateamento dos custos de transação e informação, produzindo um ambiente mais propício à especialização e, consequentemente, ao aumento da produtividade e à mudança tecnológica na economia.

Dentro da literatura, diferentes tipos de trabalhos, utilizando diferentes abordagens e os mais variados tipos de dados, buscaram esclarecer questões empíricas e teóricas acerca da relação entre setor financeiro e crescimento econômico. La Porta, Lopez-de-Silanes e Shleifer (2002) usam o grau de participação pública no setor bancário como medida de desenvolvimento financeiro. Os autores utilizaram dados de porcentagem de bancos governamentais de diversos países e concluíram que maior proporção de propriedade bancária governamental está associada a menor desenvolvimento financeiro e menor crescimento da renda per capita e produtividade.

Levine e Zervos (1998) estudaram a causalidade entre desenvolvimento bancário, mercado acionário e crescimento econômico. Os autores construíram diversas medidas de desenvolvimento do mercado acionário para uma amostra de 42 países ao longo do período de 1976 a 1993 e seus resultados são consistentes com a visão de que maior liquidez no mercado acionário é benéfica para o crescimento econômico de longo prazo e que desenvolvimento bancário é também uma variável significativa para explicar o crescimento econômico.

Utilizando dados micro-econômicos do setor industrial de diversos países, Rajan e Zingales (1998) procuraram encontrar evidências empíricas para um canal teórico por meio do qual a 
estrutura financeira estaria conectada ao crescimento econômico: o barateamento do custo de financiamento externo das firmas. Os testes empíricos mostraram que, na medida em que se desenvolve o mercado financeiro, firmas jovens e mais dependentes de financiamento externo se beneficiam do mercado de crédito e são capazes de se expandir relativamente mais rápido. Considerando que as firmas mais dependentes de financiamento são em geral as mais jovens e com projetos inovadores, a conclusão do trabalho leva a crer que o nível de desenvolvimento financeiro seria medido, em última instância, por sua capacidade de financiar a inovação e, sob este aspecto, o trabalho se aproxima da linha de pensamento de Schumpeter (1912).

Dessemelhante a autores favoráveis a uma linha de argumentação unidirecional do desenvolvimento financeiro para o crescimento econômico, Demetriades e Hussein (1996) utilizaram a abordagem de séries temporais para a investigação da relação de causalidade e encontraram evidências de causalidade bi-direcional utilizando dados de 16 países em desenvolvimento. Arestis e Demetriades (1997) também encontram que a hipótese de "finance-led growth" só é sustentada para alguns países e que, desta forma, conclusões gerais não podem ser tiradas. Uma maneira de se explicar teoricamente a evidência empírica de causalidade bi-direcional seria a de que "o aumento da eficiência do setor financeiro leva ao crescimento do produto, que, por seu turno, gera demandas adicionais por depósitos e serviços financeiros. Em síntese, o desenvolvimento do sistema financeiro e o crescimento econômico são determinados conjuntamente".(MATOS,2002)

Arestis e Demetriades (1998) também criticam os estudos que se utilizam de abordagens cross-section para avaliar a questão da causalidade. Segundo os autores, trabalhos que se baseiam em dados de cross-section sofrem de falhas graves por não considerarem características específicas de cada país, assumindo a hipótese implícita que os mesmos parâmetros se aplicam para todos os países da amostra. Assim, a recomendação é que, para estudos baseados em testes de causalidade de Granger, sejam feitos estudos de caso, país por país. 


\subsection{Evidências para o Brasil}

No Brasil, diversos estudos já foram realizados na mesma linha da literatura internacional, buscando captar o impacto do desenvolvimento financeiro sobre o crescimento econômico. As evidências empíricas aqui encontradas são variadas, mas, em geral, se alinham com a argumentação de que o sistema financeiro é um importante fator na determinação do crescimento econômico e, mais ainda, que o sistema financeiro causa ou precede temporalmente o crescimento econômico.

Uma análise ampla do sistema financeiro brasileiro é apresentada em Goldfajn, Hennings e Mori (2003). Segundo os autores, o sistema financeiro no Brasil passou por uma brusca transição entre dois modelos bastante distintos em um período de pouco mais de uma década.

Antes do Plano Real, num contexto de alta inflação, o sistema financeiro brasileiro era marcado por uma forte presença de bancos estatais, um número limitado de bancos estrangeiros, grande volume de crédito direcionado e o lucro dos bancos era significativamente baseado nas receitas associadas à alta inflação. À medida que a economia brasileira iniciou seu processo de abertura financeira e comercial, o sistema financeiro também iniciou um processo de conversão para um sistema mais moderno, com um número reduzido de bancos públicos, aumento do número de bancos estrangeiros, redução do volume de crédito direcionado e bancos bem capitalizados, cujos lucros independem da inflação.

Embora tenha havido melhora nestes aspectos, os autores ressaltam que, comparado a outros países, o volume de crédito em relação ao PIB no Brasil ainda é pequeno, os spreads bancários permanecem altos e avanços ainda devem ser feitos no sentido de produzir um ambiente mais favorável e previsível para o investimento e a tomada de decisão.

Matos (2002) apresenta uma abrangente revisão da literatura relacionada a sistema financeiro e desenvolvimento econômico e, em sua análise empírica, o autor adota a metodologia do teste de causalidade proposto por Granger. Com a utilização de dados em séries temporais para os períodos 1947-2000, 1963-2000 e 1970-2000 e indicadores financeiros representados por: $i)$ razão crédito bancário ao setor privado/PIB, ii) crédito do sistema financeiro ao setor privado/PIB e iii) recursos do público confiados ao sistema financeiro/M2, os resultados encontrados apontam para a existência de impactos diretos e unidirecionais partindo do sistema financeiro para o crescimento econômico. 
Utilizando metodologia semelhante, Marques Jr. e Porto Jr. (2004) apresentam testes de causalidade de Granger para dados de séries temporais brasileiras no período de 1950-2000. O trabalho mede o nível de desenvolvimento do setor financeiro em três dimensões: tamanho, nível de atividade e eficiência utilizando proxies destas dimensões, tanto para o sistema bancário, como para o mercado de capitais. Os resultados alcançados indicam que a relação de causalidade é inequívoca, partindo do desenvolvimento financeiro para o crescimento econômico, quando são utilizados os indicadores do sistema bancário. Quando se utilizam as proxies do mercado de capitais, os resultados são inconclusivos.

Ainda com a preocupação de analisar o sentido da causalidade entre finanças e crescimento, Rocha (2007) utiliza dados estaduais de alguns indicadores financeiros selecionados para avaliar a direção da causalidade entre sistema financeiro e desenvolvimento econômico, em uma análise de painel. $\mathrm{O}$ autor chega a dois resultados particularmente interessantes. $\mathrm{O}$ primeiro é que, utilizando dados anuais, os indicadores financeiros Granger-causam o produto, resultado que se alinha com grande parte da literatura internacional. O segundo resultado que merece destaque é que, utilizando dados dos mesmos indicadores, porém com periodicidade mensal, os resultados tornam-se difusos e parece haver evidências de que o produto Granger-causa os indicadores financeiros. Rocha (2007) justifica esta inversão de resultados pela natureza de longo prazo dos fenômenos por trás da relação entre sistema financeiro e crescimento. Quando se consideram dados de periodicidade curta, representando o curto prazo, entende-se que o sistema financeiro apenas reflete as condições reais da economia.

Há ainda diversos outros trabalhos aplicados ao Brasil que poderiam ser mencionados, mas a ênfase aqui será dada aos já citados Matos (2002), Marques Jr. e Porto Jr. (2004) e Rocha (2007) pelo fato destes trabalhos se ocuparem da questão da causalidade. Ênfase especial será dada a Rocha (2007), já que a metodologia aqui empregada seguirá a adotada naquele trabalho. 


\subsection{Enfoque Regional}

Tendo em vista o elevado nível de heterogeneidade regional do sistema financeiro no Brasil, evidenciado pela distribuição desigual de crédito e serviços bancários, uma das preocupações deste trabalho será fornecer tratamento regional às questões empíricas. O enfoque regional é também objeto de atenção dos diversos trabalhos que serão apresentados nesta seção.

A produção teórica sobre os impactos regionais do sistema financeiro pode ser considerada reduzida uma vez que os modelos tradicionais supõem a convergência das taxas de juros entre os espaços sub-nacionais (como resultado da informação perfeita e da livre mobilidade de capitais) e a incapacidade, por parte das regiões, de implementar políticas monetárias próprias. Sendo assim, não haveria porque admitir que a política monetária e o próprio sistema financeiro não sejam neutros do ponto de vista regional (CAVALCANTE, 2006). Entretanto, embora escassas, são também crescentes e variadas as contribuições teóricas sobre o tema, incluindo linhas de pensamento que variam desde monetaristas, novo-keynesianos até pós-keynesianos.

Greenwald, Levinson e Stiglitz (1993), pesquisadores vinculados à escola novo-keynesiana, exploram a relação entre desenvolvimento regional e sistema financeiro com base na existência de imperfeições no mercado de capitais, estendendo o conceito de assimetria de informações de Stiglitz e Weiss (1981) ao nível regional. Segundo os autores, em um mundo de informação imperfeita e assimetricamente distribuída, a teoria de que a política monetária é neutra ao nível regional torna-se inválida, já que estes fatores contribuem para sustentar retornos diferentes do capital entre as regiões.

Beare (1976) deu enfoque monetarista à questão dos impactos regionais da moeda e do sistema financeiro e concluiu que estes impactos se restringem às fricções de curto prazo. Os impactos diferenciados da política monetária nacional nos níveis de renda regionais se dariam em função de diferenças nas elasticidades renda da demanda entre as regiões. A conclusão geral enunciada por Beare é de que "os efeitos iniciais de uma mudança monetária se dão nas taxas do produto real... os efeitos de longo-prazo são sentidos principalmente (e talvez. totalmente) no nível de preços". (BEARE, 1976, p.58)

Os trabalhos de Dow (1987) e Chick e Dow (1988), da escola pós-keynesiana, tomam o mercado como imperfeito e a moeda elemento ativo no processo econômico. Sua teoria é 
embasada nos conceitos de preferência pela liquidez e na hipótese de que o desenvolvimento regional ocorre em consequiência de um processo de auto-reforço. Em síntese, sua teoria sugere que "a relação entre o sistema financeiro e o desenvolvimento regional envolve não apenas a oferta de fundos para empréstimos, mas também sua demanda, associada aos ciclos de negócios nas regiões centrais e periféricas e aos diferentes níveis de preferência pela liquidez exibidos em cada uma delas". (CAVALCANTE, 2006)

Alguns exemplos de trabalhos aplicados ao Brasil que levam em consideração aspectos regionais em suas modelagens empíricas são Zara (2006) e Rocha (2007). Zara (2006) procurou verificar os impactos regionais do desenvolvimento financeiro no Brasil utilizando dados estaduais entre 1995 e 2003 e a razão crédito bancário sobre o PIB como indicador de desenvolvimento financeiro. O já mencionado trabalho de Rocha (2007), utilizando dados estaduais entre 1995 e 2002, procurou esclarecer a relação de causalidade entre desenvolvimento financeiro e crescimento econômico.

Outra referência importante, que aborda o tema de causalidade entre crédito bancário e atividade econômica sob uma ênfase local, é Reichstul e Lima (2006). O trabalho adota o instrumental de Vetores Auto-Regressivos na tentativa de estimar, por meio do teste de Granger, a direção da causalidade entre as variáveis de crédito e atividade econômica da Região Metropolitana de São Paulo, no período de janeiro de 2002 a dezembro de 2003. Os testes realizados "indicaram a existência de uma relação causal de mão dupla, em que tanto o desenvolvimento financeiro causa o econômico quanto este causa aquele". (REICHSTUL;LIMA,2006)

Neste trabalho, utilizaremos dados municipais de crédito e crescimento econômico, assim como fizeram Pires (2005) e Kroth e Dias (2006). Pires (2005) resgata a estratégia de King e Levine (1993) com o intuito de identificar o impacto do crédito sobre o crescimento econômico dos municípios. Os resultados mostram que o sistema financeiro possui papel importante no desenvolvimento dos municípios brasileiros, porém a análise regional mostra resultados divergentes. O impacto do mercado financeiro sobre o desenvolvimento só é encontrado para a região Sudeste, as demais regiões não permitem que se chegue a tal conclusão. Este resultado leva o autor a concluir que deve haver um nível mínimo de desenvolvimento a partir do qual o mercado financeiro passa a contribuir para o desenvolvimento econômico. 
No caso de Kroth e Dias (2006), além do crédito bancário, os autores buscaram explicar a contribuição do capital humano na determinação do crescimento dos municípios brasileiros. A metodologia econométrica utilizada assemelha-se a que será utilizada aqui, com o uso da técnica de Momentos Generalizados para a solução do problema de causalidade reversa em um contexto de painéis dinâmicos. Os resultados, mais uma vez, corroboram a significância das variáveis financeiras na determinação do crescimento econômico.

Tendo em vista a ampla literatura relacionada ao tema "Sistema Financeiro e Crescimento Econômico", iremos, a partir do capítulo que se segue, delimitar o tema para um campo mais específico: a importância de Sistemas Financeiros Rurais para o crescimento agropecuário dos municípios brasileiros. A intenção é avaliar empiricamente e, levando em consideração aspectos regionais, a contribuição do crédito rural para o crescimento dos municípios ao longo do período 1999-2004. Mais especificamente, visamos esclarecer a relação de causalidade entre esta modalidade específica de crédito e o produto agropecuário municipal.

\subsection{Crédito Rural e Desenvolvimento Rural}

Argumentos semelhantes aos apresentados por Levine (1997) para justificar teoricamente a visão de que o sistema financeiro estimula o crescimento econômico são também aplicáveis ao meio rural. Da mesma forma, o crescimento do setor rural se dá através da acumulação de capital e da inovação. O sistema financeiro atua por meio do levantamento de fundos, mobilização de poupança, facilitando o planejamento das atividades, permitindo o acesso à melhor tecnologia e contribuindo para o aproveitamento de novas oportunidades econômicas.

Segundo Assunção e Chein (2007), o mau funcionamento do mercado de crédito é um dos ingredientes necessários à ocorrência da "armadilha da pobreza"2. A falta de recursos necessários ao financiamento do investimento limita a capacidade das famílias de escapar da pobreza. Do ponto de vista agregado, essa incapacidade gera uma ineficiência, visto que os pobres não conseguem sair da sua condição de pobreza não porque são menos produtivos ou desprovidos das qualificações necessárias, mas porque imperfeições de mercado impedem a realização plena de suas capacidades.(ASSUNÇÃO; CHEIN, 2007, p. 368)

\footnotetext{
${ }^{2}$ O conceito de "armadilha da pobreza" é de natureza dinâmica. Trata-se da situação na qual um indivíduo ou família que parta de uma condição inicial de pobreza não consegue sair dessa condição.
} 
O trabalho de Assunção e Chein (2007) documenta a evolução recente do racionamento de crédito para a população rural brasileira. $\mathrm{O}$ conceito de racionamento presente no trabalho está associado à correlação entre riqueza e escolhas, de maneira que, se o racionamento é ativo, então a riqueza exerce muita influência sobre as escolhas das famílias. Partindo deste conceito, os autores criaram, com base em dados microeconômicos dos Censos Demográficos de 1991 e 2000, uma medida de riqueza e associaram a ela duas variáveis de escolha: educação infantil e probabilidade de o chefe de família ser um empregador.

Segundo os autores, o racionamento é ativo em todas as regiões do Brasil e há espaço para melhorias nas condições de acesso das famílias rurais. Entretanto, não é claro que as políticas de crédito voltadas para a agricultura sejam capazes de resolver este problema, já que os resultados dos testes empíricos mostraram que as áreas onde houve maior expansão do crédito bancário foram justamente as áreas onde o racionamento de crédito sofreu maior aperto no período analisado.

Gonzales e Costa (1998) defendem o ponto de vista de que as políticas setoriais voltadas para a agricultura, notadamente as de crédito, são fundamentais para estimular a demanda por tecnologia e conseqüentes ganhos de produtividade no setor. $\mathrm{O}$ produtor rural, quando estimulado por políticas setoriais e de crédito favoráveis, tende a expandir sua produção e introduzir inovações tecnológicas, dinamizando a atividade agrícola.

De acordo com Kroth, Dias e Giannini (2006), a busca pela melhor maneira de se desenvolver um setor que possui riscos mais complexos do que outras atividades e que sempre esteve posicionado de forma estratégica para as metas econômicas do país suscita debates sobre alguns pontos, como: $i$ ) a necessidade de subsidiar a atividade rural e em que montantes, ii) a forma como os financiamentos devem ser geridos e iii) o questionamento sobre a efetividade do crédito rural em alcançar seus objetivos, no tocante à produção, produtividade e retornos à sociedade.

Segundo Kumar (2005) os governos tendem a responder aos desafios acima mencionados com a aplicação de uma receita que combina direcionamento setorial de crédito (controles de quantidade) e taxas de juros abaixo das taxas de mercado (controles de preço), além de recursos de fundos e programas governamentais canalizados através de bancos públicos. A autora argumenta que, embora este tipo de programa tenha sido bem sucedido no que tange ao 
aumento do volume de recursos concedidos ao setor rural, pouca ênfase é dada à recuperação dos empréstimos e à sustentabilidade institucional deste modelo.

A abordagem agressiva de oferta dirigida de crédito, adotada por muitos países inclusive o Brasil, não tiveram, segundo Meyer (2000), resultados positivos. Quantidades maciças de fundos foram fornecidas à agricultura, cotas de crédito foram impostas aos bancos comerciais e bancos e cooperativas especializados em desenvolvimento agrícola foram criados em alguns países. Entretanto, muitas das instituições criadas faliram, muitas se mostraram fracas e precisaram ser recapitalizadas, e permaneceu a dificuldade dos pobres em obter acesso ao sistema financeiro. Em suma, os segmentos e mecanismos do sistema financeiro criados para atender à clientela rural caracterizaram-se por ter alcance limitado e fraca sustentabilidade. ${ }^{3}$

Klein et al.(1999) assinalam os aspectos políticos por detrás da implementação dos mecanismos financeiros rurais. Segundo os autores, muitos bancos de desenvolvimento foram criados por propósitos políticos e não foram desenhados de forma a se tornarem instituições financeiras viáveis. Nessas condições, a disponibilidade dos recursos torna-se irregular por estar condicionada a decisões e interesses políticos. Além disso, em geral, o desempenho destas instituições é medido em termos do valor desembolsado, de maneira que esses bancos tendem a emprestar mais para grandes e bem estabelecidos fazendeiros. Nesse ponto, se revela o comportamento rent-seeking dos grandes produtores, que se beneficiam de taxas subsidiadas garantidas pelo governo. Klein et al.(1999) destacam ainda que o fato destes bancos serem destinados exclusivamente a empréstimos para setores rurais faz com que estes estejam sujeitos a uma alta concentração de riscos.

Poucos são os trabalhos que se destinaram a avaliar empiricamente a capacidade do sistema financeiro rural em afetar o crescimento econômico. Uma referência internacional é Khandker (2005), que procurou examinar os efeitos das microfinanças na redução da pobreza, tanto no nível individual do tomador de crédito, quanto no nível agregado dos municípios. O autor utilizou dados microeconômicos da população rural de Bangladesh e teve a preocupação de captar os efeitos externos das microfinanças na tentativa de responder à questão: os impactos do microcrédito são grandes o suficiente para justificar o seu apoio em detrimento de usos alternativos? Os resultados das estimações sugerem que as microfinanças contribuem para a

\footnotetext{
${ }^{3}$ Exemplos de instituições financeiras do tipo mencionado por Meyer e que foram reformadas com sucesso são o Bank Rayat Indonesia (BRI) na Indonésia e o Bank for Agriculture and Agricultural Cooperatives (BAAC) na Tailândia.
} 
redução da pobreza do indivíduo tomador do crédito, especialmente das mulheres. Mais ainda, as microfinanças externalizam este efeito para a economia local, contribuindo para a redução da pobreza do município.

Outro estudo importante, desta vez mais relacionado ao acesso a serviços financeiros em áreas rurais é Burgess e Pande (2004). Os autores exploraram empiricamente os efeitos de uma regra de licenciamento para abertura de filiais de bancos comerciais adotada na Índia entre 1977 e 1990. De acordo com tal regra, um banco comercial que fosse abrir uma filial em uma localidade que já contasse com outras agências bancárias, deveria abrir 4 outras agências em localidades desprovidas de bancos. A intenção do estudo foi testar em que medida a expansão do setor bancário, promovida pelo governo, por meio da imposição da regra, contribuiu para a redução da pobreza na Índia. Os resultados fornecem evidências de que a ampliação do acesso proporcionada pela adoção da regra contribuiu significativamente para a redução da pobreza rural no período considerado e manteve inalterados os níveis de pobreza urbana.

No caso do Brasil, alguns estudos se propuseram a examinar o efeito de programas ou políticas específicas, como é o caso do Programa Nacional de Fortalecimento da Agricultura Familiar (PRONAF) ${ }^{4}$, sobre o qual muitos trabalhos se debruçaram na tentativa de apreender seus efeitos. Feijó (2003) oferece um estudo do impacto do PRONAF sobre a produtividade da agricultura familiar. A principal conclusão do estudo é que a produtividade das culturas beneficiadas pelo PRONAF vem crescendo a taxas anuais não muito diferentes das taxas associadas às culturas familiares excluídas do programa. Tal fato indica a ausência de impacto produtivo significativo do programa. A respeito do PRONAF, outros estudos como Magalhães et al.(2006) e Cardoso e Ortega (2000) chegaram a resultados divergentes.

Kroth, Dias e Giannini (2006) realizam uma análise econométrica de um painel de dados de municípios paranaenses, buscando identificar se o crédito rural teve influência no produto per capita agrícola destes municípios no período 1999-2003. Os resultados do trabalho corroboram a tese de que o crédito agrícola é um mecanismo importante para o aumento da produtividade no campo e crescimento do produto. Verificou-se ainda que a variável que melhor explica o produto per capita ao longo dos anos é o crédito para custeio. Segundo os autores, o crédito para custeio torna possível ao produtor adquirir as matérias-primas

\footnotetext{
${ }^{4}$ O Programa Nacional de Fortalecimento da Agricultura Familiar - Pronaf - foi criado em 1995 pelo Governo Federal com o objetivo de atender ao pequeno produtor rural mediante apoio financeiro ao desenvolvimento de suas atividades agropecuárias e não agropecuárias exploradas com a força de seu trabalho e de sua família.
} 
necessárias para a produção através de capital de giro barato. $\mathrm{O}$ menor custo do capital possibilita melhores retornos, que devem ser reinvestidos na produção. Já o crédito para investimento não se mostrou significante nas regressões.

No que tange ao subtema "Crédito Rural e Desenvolvimento Rural”, Kroth, Dias e Giannini (2006) representam uma referência de suma importância, já que a metodologia utilizada pelos autores para dados de municípios paranaenses assemelha-se à que será empregada aqui para dados municipais de todo o Brasil. Os autores estimam um modelo dinâmico em painel de dados, proposto por Arellano e Bond (1991), na tentativa de contornar o problema de causalidade reversa. Seus resultados apontam para a importância do crédito rural para o crescimento do produto agrícola dos municípios paranaenses e corroboram, portanto, o ponto de vista de que a utilização do crédito rural é um mecanismo eficiente para melhorar a produtividade no campo. 


\section{Direcionando a questão: Sistemas Financeiros Rurais}

Este capítulo irá discorrer sobre um instrumento financeiro específico, o crédito rural, sobre o qual a análise empírica de causalidade será direcionada. Na primeira seção, será realizada uma apresentação geral do sistema de crédito no Brasil, em especial, do sistema de crédito rural, ressaltando-se os aspectos regionais mais relevantes neste contexto. A segunda parte discute as peculiaridades do setor rural que justificam a presença governamental neste mercado e apresenta a legislação que discorre sobre suas exigibilidades. Em seguida, uma seção será dedicada a apresentar e evolução histórica do crédito rural desde 1965 até hoje. Finalmente, será apresentada a justificativa para a escolha da variável crédito rural para a investigação empírica.

\subsection{Descrição do mercado de crédito brasileiro em uma perspectiva regional}

Antes de apresentar o crédito rural como instrumento financeiro específico a ser analisado pela parte empírica deste trabalho, torna-se conveniente apresentar, em linhas gerais, uma descrição do mercado de crédito bancário brasileiro no qual se insere o mercado de crédito rural.

O crédito bancário é importante fonte de financiamento no Brasil, estando ainda à frente de outros instrumentos para captação de recursos, tais como a emissão de ações ou o financiamento externo. Mesmo assim, autores como Goldfajn, Hennings e Mori (2003) afirmam que, comparado a outros países, o Brasil ainda apresenta uma baixa participação relativa do crédito sobre o PIB. O Gráfico 1 apresenta a evolução da proporção crédito total/ PIB no Brasil para o período recente de janeiro/1999 a março/2008. Embora tenha crescido no período apresentado, a participação relativa do crédito sobre o PIB, situada em $35,87 \%$ em março/2008, é pequena quando comparada a de países desenvolvidos, como por exemplo, Estados Unidos (146\%), Alemanha (118\%) e Japão (107\%). Esta relação fica abaixo até mesmo de países latino-americanos como Chile (61\%) e Uruguai $(53 \%){ }^{5}$

\footnotetext{
${ }^{5}$ Os dados internacionais se referem ao crédito privado sobre o PIB e a fonte original é o banco de dados do FMI: IMF International Financial Statistics, 2004.
} 
Gráfico 1 - Crédito total do sistema financeiro como proporção do PIB (\%)

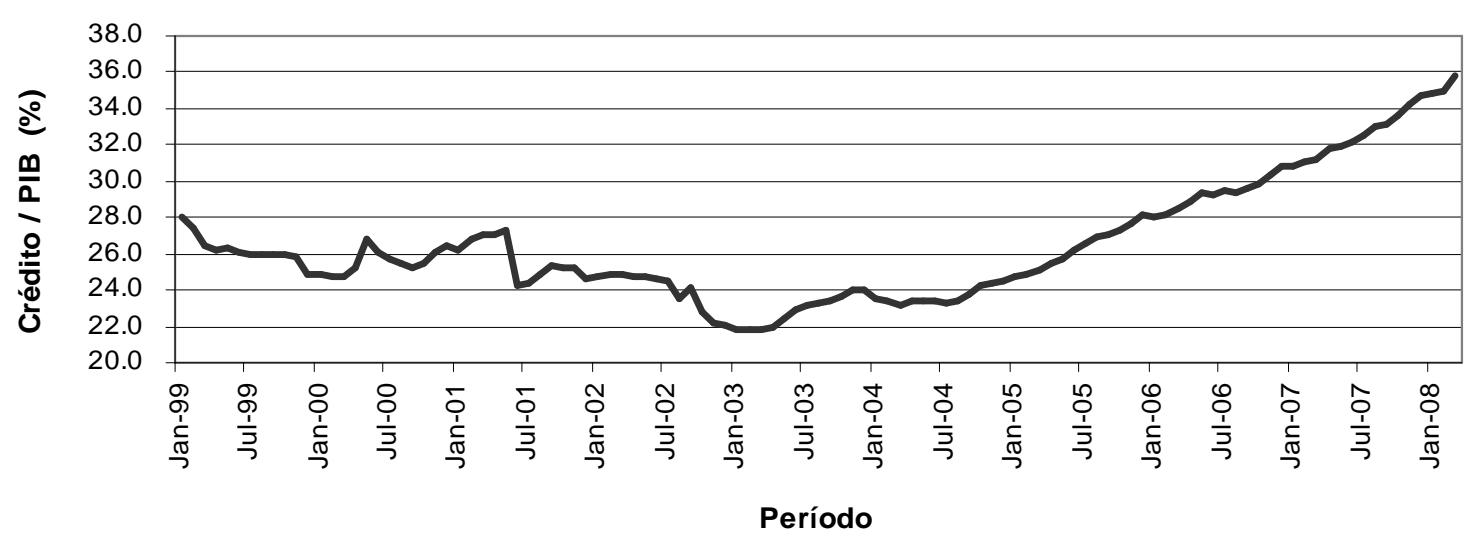

Fonte: Banco Central do Brasil

Para se ter uma idéia do "tamanho" do mercado de capitais de um país, utiliza-se freqüentemente um índice de "capitalização relativa". A capitalização relativa é obtida pela razão entre o valor do total das ações negociadas no mercado e o PIB. O Gráfico 2 apresenta este índice calculado para o Brasil em comparação com a média dos países emergentes e com a média dos países desenvolvidos. A capitalização de mercado do grupo de países desenvolvidos representou, em média, quase o dobro daquela do grupo de países emergentes e esta distância é ainda mais ampliada quando se analisa especificamente o caso do Brasil. Essa diferença parece fornecer um indício de que o desenvolvimento econômico está positivamente correlacionado com o desenvolvimento do mercado de capitais, nesse caso medido pelo índice de capitalização relativa. 
Gráfico 2 - Capitalização relativa (\% PIB)

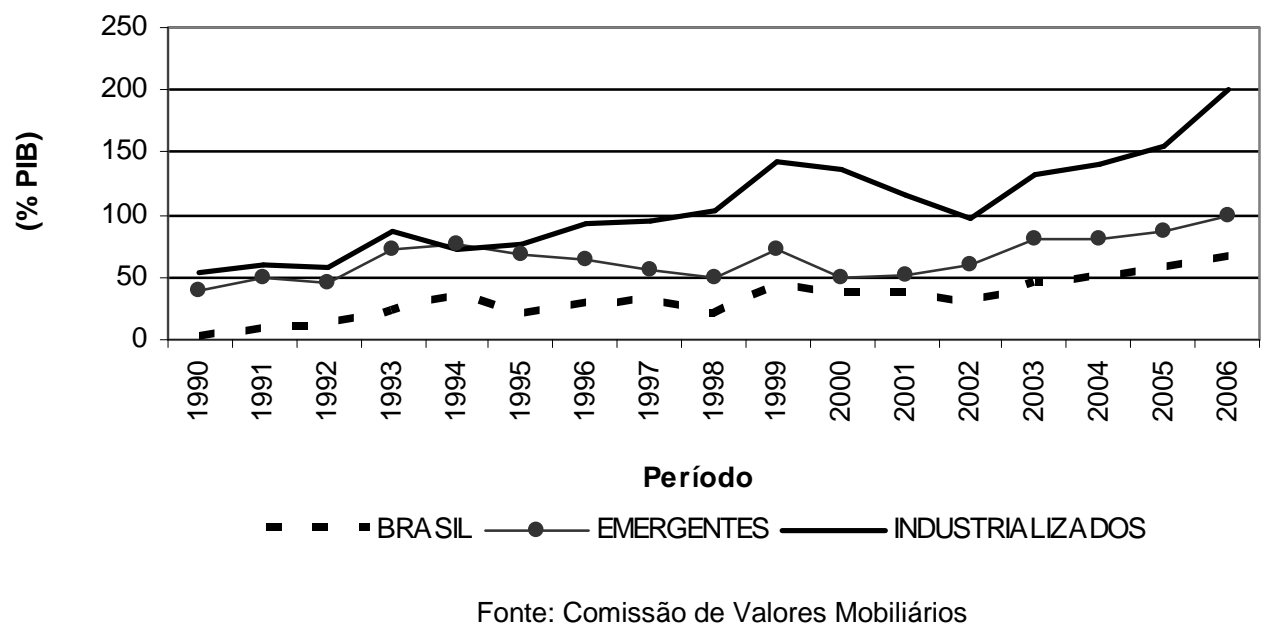

Embora o financiamento por meio da emissão de ações esteja ganhando importância crescente no Brasil, especialmente a partir de 2005, esta expansão é decorrente da ação do segmento de empresas de grande porte, capazes de captar recursos em fontes alternativas. No campo das pequenas e médias empresas, ainda é o crédito bancário a fonte de financiamento mais utilizada.

Tendo em vista a relevância do mercado de crédito bancário como forma de financiamento no Brasil, é importante analisar como se distribuem os serviços bancários e financeiros dentro do país. A Tabela 1, apresentada a seguir, mostra a distribuição do Produto Interno Bruto (PIB) e de serviços financeiros como aplicações bancárias, poupança e número de agências entre os estados brasileiros e sua participação percentual no total do Brasil. É notável a distribuição desigual destes atributos entre as regiões, distribuição esta que segue padrão semelhante ao da concentração do produto e, mais uma vez, sugere alguma correlação entre nível do produto e desenvolvimento do setor financeiro.

A região Sudeste, além de concentrar mais de $50 \%$ de todo o produto nacional, é também responsável por mais de $60 \%$ do total das aplicações bancárias e depósitos de poupança e por mais da metade do número total de agências bancárias. Do lado oposto está a região Norte, com a menor representação do produto $(5,29 \%)$ assim como os menores valores para os serviços financeiros. O Estado de São Paulo, mesmo comparado aos outros estados da região Sudeste, apresenta posição de destaque, confirmando a mais alta concentração da renda e dos serviços financeiros do país nesta localidade. 
Tabela 1 - PIB e Serviços Financeiros: participação dos estados e regiões no total do país (\%)

\begin{tabular}{|c|c|c|c|c|}
\hline UF / Região & PIB & $\begin{array}{l}\text { Aplicações } \\
\text { Bancárias }\end{array}$ & Poupança & $\begin{array}{c}\mathbf{N}^{\circ} \text { de } \\
\text { Agências }\end{array}$ \\
\hline AC & 0.18 & 0.03 & 0.09 & 0.15 \\
\hline AM & 2.03 & 0.33 & 0.51 & 0.74 \\
\hline AP & 0.21 & 0.04 & 0.07 & 0.08 \\
\hline PA & 1.94 & 0.70 & 0.88 & 1.52 \\
\hline RO & 0.55 & 0.12 & 0.20 & 0.45 \\
\hline $\mathbf{R R}$ & 0.11 & 0.02 & 0.06 & 0.08 \\
\hline TO & 0.27 & 0.17 & 0.11 & 0.41 \\
\hline Norte & 5.29 & 1.41 & 1.92 & 3.43 \\
\hline$A L$ & 0.65 & 0.45 & 0.62 & 0.66 \\
\hline BA & 4.92 & 2.81 & 3.14 & 4.42 \\
\hline CE & 1.88 & 1.24 & 1.76 & 1.98 \\
\hline MA & 0.94 & 0.62 & 0.62 & 1.48 \\
\hline PB & 0.84 & 0.43 & 0.75 & 0.87 \\
\hline PE & 2.70 & 1.56 & 2.38 & 2.53 \\
\hline PI & 0.49 & 0.35 & 0.48 & 0.61 \\
\hline RN & 0.90 & 0.44 & 0.67 & 0.76 \\
\hline SE & 0.74 & 0.36 & 0.64 & 0.89 \\
\hline Nordeste & 14.06 & 8.26 & 11.06 & 14.20 \\
\hline DF & 2.46 & 9.72 & 1.93 & 1.57 \\
\hline GO & 2.34 & 1.43 & 1.51 & 3.14 \\
\hline MS & 1.13 & 0.67 & 0.60 & 1.32 \\
\hline MT & 1.58 & 0.95 & 0.55 & 1.29 \\
\hline Centro-Oeste & 7.51 & 12.77 & 4.59 & 7.32 \\
\hline ES & 1.95 & 1.01 & 1.54 & 1.73 \\
\hline MG & 9.43 & 5.11 & 9.18 & 10.90 \\
\hline RJ & 12.60 & 9.32 & 15.71 & 9.36 \\
\hline SP & 30.94 & 49.90 & 39.26 & 32.31 \\
\hline Sudeste & 54.92 & 65.34 & 65.69 & 54.30 \\
\hline PR & 6.15 & 5.09 & 5.48 & 7.70 \\
\hline RS & 8.09 & 5.23 & 8.30 & 8.24 \\
\hline SC & 3.97 & 1.87 & 2.97 & 4.80 \\
\hline Sul & 18.21 & 12.19 & 16.75 & 20.74 \\
\hline
\end{tabular}

Ainda com relação ao mercado de crédito como um todo, outro ponto válido de ser analisado é a divisão do crédito total entre recursos livres e direcionados. A partir da análise dos dados da Tabela 2, observa-se que no período entre 2000 e 2007, a participação relativa do crédito com recursos livres sobre o crédito total aumentou, tendo como contrapartida a queda da participação do crédito com recursos direcionados. Esta trajetória de queda do segmento direcionado segue, embora de forma menos abrupta, uma tendência observada em outros países do mundo. Alguns exemplos são o Equador $^{6}$, que em 1984 tinha 52,7\% do crédito total representados pelo segmento direcionado, e passou, em 1992, para 9,2\% e a Coréia ${ }^{7}$, que em 1975 tinha mais de $70 \%$ de crédito direcionado e passou, já em 1999, para pouco mais de $30 \%$.

\footnotetext{
${ }^{6}$ Fonte: Superintendência de Bancos e Seguros - Republica del Ecuador.

${ }^{7}$ Fonte: The Bank of Korea.
} 
Tabela 2 - Crédito com recursos livres e direcionados como proporção do crédito total (\%)

\begin{tabular}{lcccccccc}
\hline & $\mathbf{2 0 0 0}$ & $\mathbf{2 0 0 1}$ & $\mathbf{2 0 0 2}$ & $\mathbf{2 0 0 3}$ & $\mathbf{2 0 0 4}$ & $\mathbf{2 0 0 5}$ & $\mathbf{2 0 0 6}$ & $\mathbf{2 0 0 7}$ \\
\hline \hline RECURSOS LIVRES & $\mathbf{5 5 . 1 2}$ & $\mathbf{6 7 . 0 6}$ & $\mathbf{6 6 . 1 1}$ & $\mathbf{6 2 . 2 3}$ & $\mathbf{6 2 . 4 3}$ & $\mathbf{6 5 . 8 2}$ & $\mathbf{6 7 . 6 8}$ & $\mathbf{6 9 . 6 9}$ \\
$\quad$ Pessoas Físicas & 18.09 & 24.39 & 24.86 & 23.97 & 25.23 & 30.37 & 32.47 & 34.07 \\
Pessoas Jurídicas & 37.03 & 42.67 & 41.25 & 38.26 & 37.20 & 35.44 & 35.21 & 35.62 \\
RECURSOS DIRECIONADOS & $\mathbf{4 4 . 8 8}$ & $\mathbf{3 2 . 9 4}$ & $\mathbf{3 3 . 8 9}$ & $\mathbf{3 7 . 7 7}$ & $\mathbf{3 7 . 5 7}$ & $\mathbf{3 4 . 1 8}$ & $\mathbf{3 2 . 3 2}$ & $\mathbf{3 0 . 3 1}$ \\
BNDES & 18.29 & 20.21 & 21.02 & 23.26 & 23.32 & 20.76 & 19.36 & 17.43 \\
Rural & 6.84 & 5.51 & 5.74 & 7.66 & 7.91 & 7.58 & 7.26 & 7.20 \\
Habitação & 18.72 & 6.31 & 6.21 & 5.97 & 5.34 & 4.77 & 4.80 & 4.84 \\
Outros & 1.04 & 0.90 & 0.93 & 0.88 & 1.01 & 1.07 & 0.90 & 0.85 \\
\hline
\end{tabular}

Fonte: Banco Central do Brasil

Verifica-se, a partir da Tabela 2, que, dentre as modalidades de crédito direcionado, o crédito rural foi a única que apresentou aumento de participação relativa ao longo do período. $\mathrm{O}$ Gráfico 3, apresentado a seguir, mostra a evolução dos recursos do crédito rural ao longo do período 1969 a 2006 e, por meio destes dados, pode-se perceber que, a partir de 1999, o crédito rural volta a apresentar uma trajetória ascendente, embora os valores concedidos sejam significativamente menores do que aqueles observados nas décadas de 1970 e $1980^{8}$.

Gráfico 3 - Crédito rural: evolução dos recursos (valores constantes de 2006*)

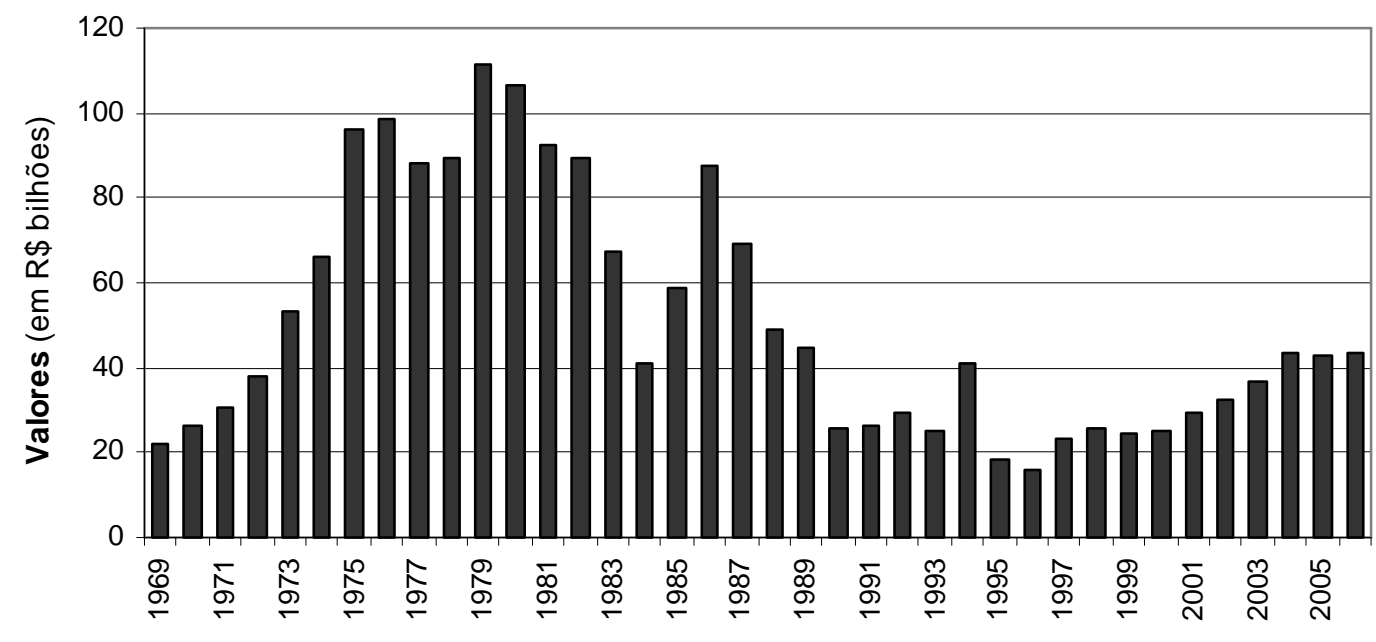

Ano

Fonte: Banco Central do Brasil

* IGP-DI - Índice Médio Anual

O crédito rural é classificado de acordo com o item financiado (agricultura ou pecuária) e a finalidade a que se destina (custeio, investimento ou comercialização). No Brasil, a maior parte do crédito rural concedido é destinada à atividade agrícola para a finalidade de custeio.

\footnotetext{
${ }^{8}$ Uma descrição mais detalhada da evolução histórica do crédito rural será apresentada na seção 2.3.
} 
O Gráfico 4 ilustra a divisão do crédito rural por atividade e finalidade de acordo com os valores observados no ano de 2006.

Gráfico 4 - Crédito rural: atividade e finalidade (2006)

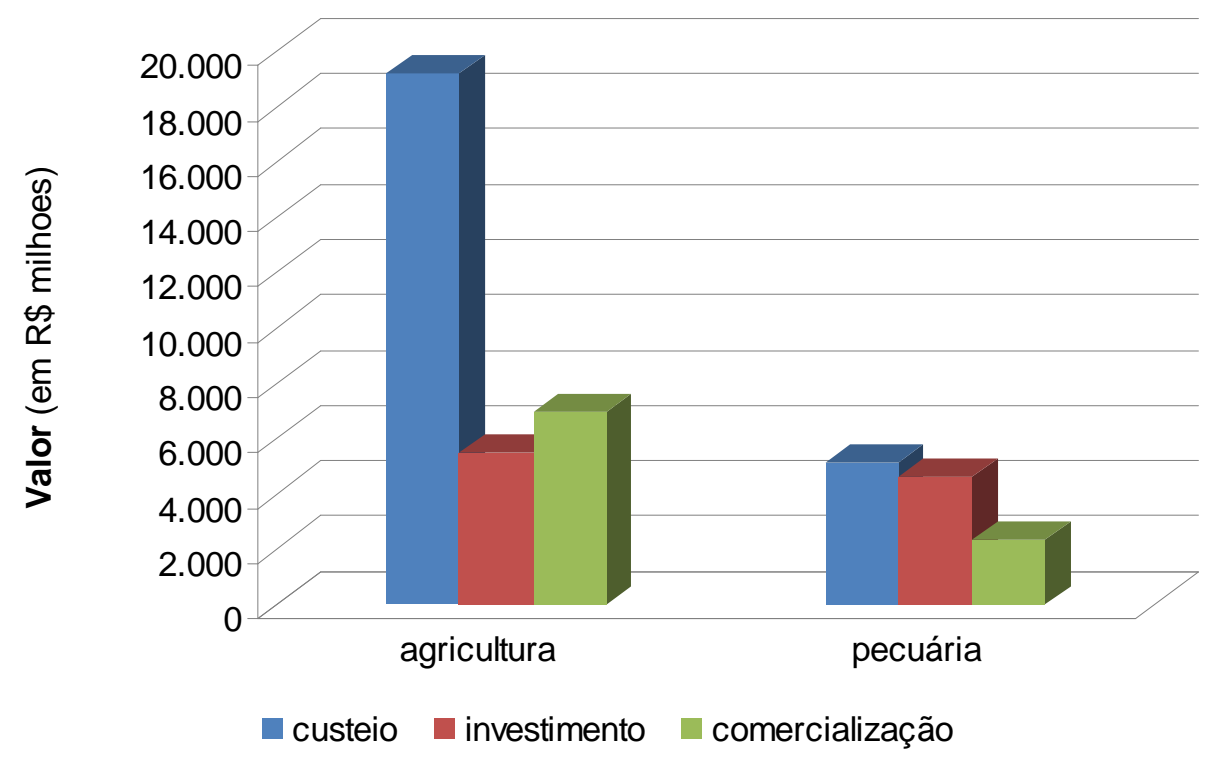

Fonte: Anuário Estatístico do Crédito Rural (2006)

Dentre os estados brasileiros, aquele que apresenta a maior concentração de recursos do crédito rural é o Rio Grande do Sul, seguido pelo Paraná. A partir do Gráfico 5, percebe-se que, no que concerne ao valor dos financiamentos, a região Sul é a mais representativa, concentrando quase $40 \%$ do total dos recursos, destinados majoritariamente à atividade agrícola. Por outro lado, é a região Nordeste que lidera o número de contratos (Gráfico 6), embora tenha um valor pouco significativo em termos de volume de financiamentos. Esta constatação sugere que a distribuição do crédito é menos concentradora ou mais pulverizada na região Nordeste, que apresenta um número maior de contratos de pequeno valor.

Gráfico 5 - Valor dos financiamentos concedidos (2006) - Participação das regiões (\%)

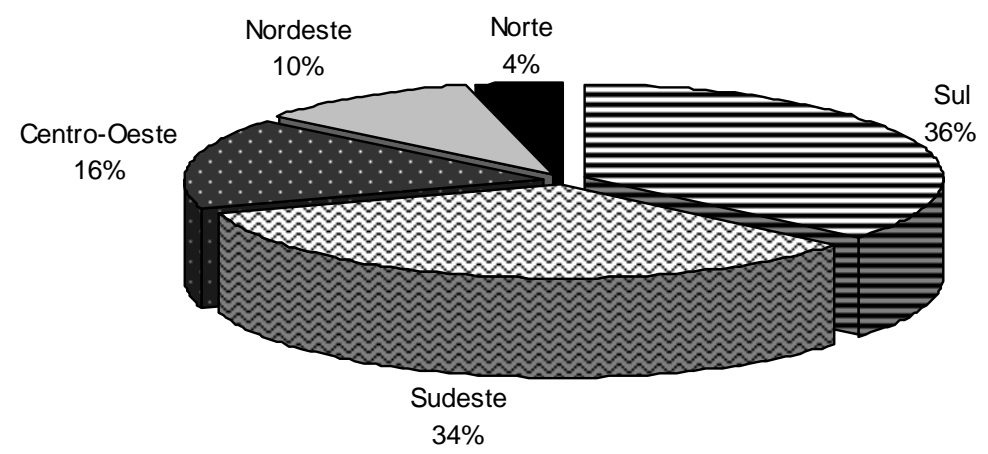

Fonte: Banco Central do Brasil - Anuário Estatístico do Crédito Rural (2006) 


\section{Gráfico 6 - Número de contratos (2006) - Participação das regiões (\%)}



Fonte: Banco Central do Brasil - Anuário Estatístico do Crédito Rural (2006)

Em 2006, do valor total das operações contratadas, 38,3\% corresponderam a financiamentos de até R \$ 60 mil, abrangendo 97\% dos contratos (Gráfico 7). Operações de valor superior a R \$ 300 mil corresponderam a 36,3\% do total do crédito concedido e a apenas $0,4 \%$ dos contratos firmados.

\section{Gráfico 7 - Crédito rural por faixa de financiamento (2006)}

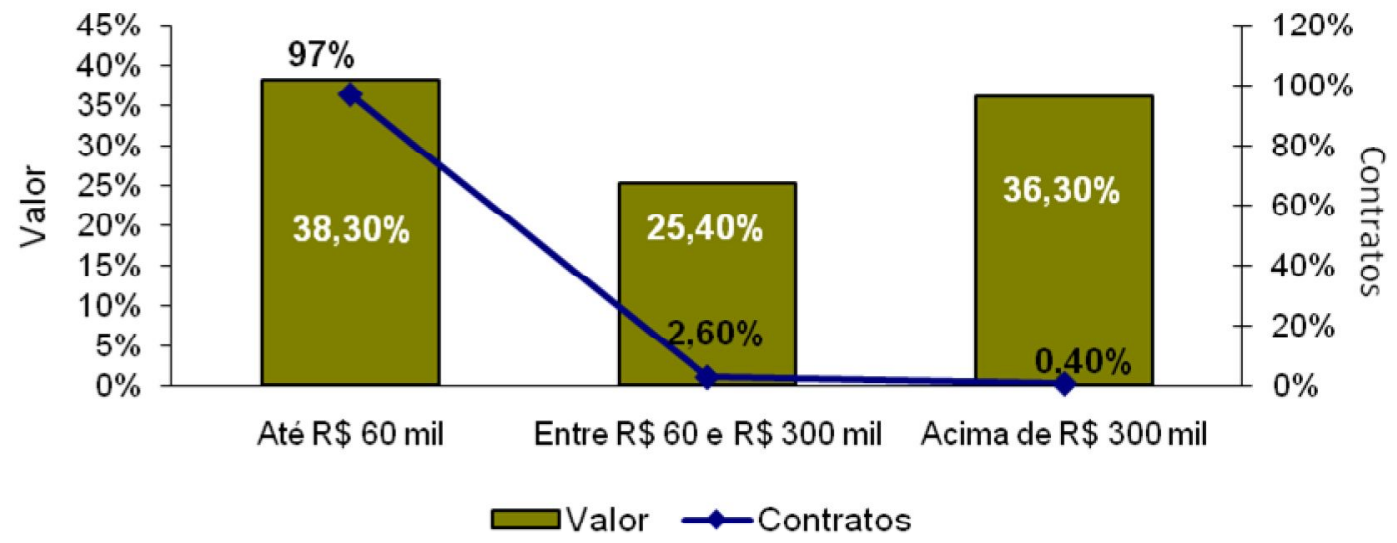

A Tabela 3 mostra o número de contratos, o valor dos financiamentos e o valor médio dos contratos firmados em cada uma das regiões. Verifica-se que a região Nordeste é realmente a região em que os contratos apresentam menor valor médio, seguramente por conta da maior concentração na região do público de mais baixa renda ${ }^{9}$ e da predominância da exploração de culturas alimentares de ciclo curto, que podem ser exploradas em pequenas propriedades e requerem menor valor de investimento. O oposto é observado na região Centro-Oeste, onde o

\footnotetext{
${ }^{9}$ Segundo o $13^{\circ}$ Boletim de Políticas Sociais do IPEA: Acompanhamento e Análise, de fato, a região Nordeste concentra $74 \%$ dos estabelecimentos familiares de menores rendimentos anuais.
} 
número de contratos é o mais baixo do país, enquanto o valor médio dos contratos é significativamente maior do que o das outras regiões.

Tabela 3 - Valor médio dos contratos rurais (2006)

\begin{tabular}{lccc}
\hline & $\begin{array}{c}\mathbf{N}^{\circ} \text { de } \\
\text { contratos }\end{array}$ & $\begin{array}{c}\text { Valor Total } \\
\text { (R\$ milhões) }\end{array}$ & $\begin{array}{c}\text { Valor médio } \\
\text { dos contratos } \\
\text { (R\$) }\end{array}$ \\
\hline \hline Centro-Oeste & 132.164 & 7.077 & $53.544,86$ \\
Sudeste & 495.018 & 14.977 & $30.255,35$ \\
Sul & 1.020 .110 & 15.716 & $15.406,04$ \\
Norte & 146.625 & 1.546 & $10.540,61$ \\
Nordeste & 1.728 .638 & 4.451 & $2.574,60$ \\
\hline
\end{tabular}

Fonte: Anuário Estatístico do Crédito Rural - Banco Central do Brasil

Observando a destinação dos recursos, constata-se que os estados brasileiros que mais recebem recursos do crédito rural, Rio Grande do Sul e Paraná, têm seus recursos destinados predominantemente ao cultivo de soja, cultura caracterizada pela produção em larga escala e em grandes propriedades. No ano de 2006, a soja representou 42,6\% do total dos recursos destinados ao financiamento de custeio de lavouras no Paraná e 28,8\% no Rio Grande do Sul. Algo semelhante ocorre na região Centro-Oeste, onde a soja representa quase $60 \%$ do financiamento destinado ao estado de Goiás, $70 \%$ dos recursos destinados ao Mato Grosso do Sul e $75 \%$ dos destinados ao Mato Grosso.

A Região Nordeste, por sua vez, lidera no número de contratos, os quais se destinam majoritariamente à produção pecuária. Entretanto, no que se refere ao valor dos financiamentos, o maior volume de recursos é destinado à agricultura, principalmente para a produção de arroz e milho, nos estados da Bahia e Ceará. ${ }^{10}$

No âmbito do crédito rural, a concessão dos financiamentos é realizada, em sua maioria, por Bancos Oficiais Federais. Ao longo de todo período analisado, entre 2000 e 2006, os Bancos Oficiais Federais foram responsáveis por conceder mais de $50 \%$ de todo o financiamento à agropecuária concedido no Brasil.

\footnotetext{
${ }^{10}$ Fonte: Anuário Estatístico do Crédito Rural 2006, Banco Central do Brasil.
} 
Tabela 4 - Financiamentos concedidos a produtores e cooperativas: por tipo de instituição (\%)

\begin{tabular}{lrrrrrrr}
\hline & $\mathbf{2 0 0 0}$ & $\mathbf{2 0 0 1}$ & $\mathbf{2 0 0 2}$ & $\mathbf{2 0 0 3}$ & $\mathbf{2 0 0 4}$ & $\mathbf{2 0 0 5}$ & $\mathbf{2 0 0 6}$ \\
\hline \hline Bancos Oficiais Federais & 50,05 & 50,51 & 55,28 & 58,90 & 57,90 & 59,77 & 51,17 \\
Bancos Privados & 42,50 & 41,93 & 35,70 & 32,72 & 34,14 & 32,91 & 40,86 \\
Cooperativas & 5,15 & 5,21 & 6,72 & 6,26 & 5,87 & 5,29 & 6,12 \\
Bancos Oficiais Estaduais & 2,30 & 2,34 & 2,30 & 2,11 & 2,09 & 2,03 & 1,85 \\
\hline
\end{tabular}

Fonte: Anuário Estatístico do Crédito Rural - Banco Central do Brasil

As fontes de recursos também fornecem uma idéia da ampla presença governamental no setor. No ano de 2006, as principais fontes de recursos utilizadas para o financiamento das atividades rurais originaram-se dos recursos obrigatórios (45,8\%), a Poupança Rural representou 18,7\%, os Fundos Constitucionais 9,2\%, o Fundo de Amparo ao Trabalhador $7,6 \%$ e o BNDES 7,3\%. Os créditos com recursos livres representaram apenas 4,3\% do total dos financiamentos concedidos em 2006.

Tabela 5 - Fontes de recursos do crédito rural (2006)

Representatividade sobre o total dos recursos (\%)

\begin{tabular}{lccc}
\multicolumn{4}{c}{ Representatividade sobre o total dos recursos (\%) } \\
\hline \multirow{2}{*}{ Fonte de Recursos } & \multicolumn{2}{c}{ Atividade } & \multirow{2}{*}{ Consolidado } \\
& Agricultura & Pecuária & \\
\hline \hline Recursos Obrigatórios & 47,88 & 40,28 & 45,77 \\
Poupança Rural & 20,36 & 14,44 & 18,72 \\
Recursos BNDES / FINAME & 8,65 & 3,83 & 7,32 \\
FAT & 6,88 & 9,35 & 7,57 \\
Recursos do Funcafé & 5,38 & 0,00 & 3,91 \\
Fundos Constitucionais & 4,41 & 21,57 & 9,16 \\
Recursos Livres & 3,02 & 7,77 & 4,33 \\
Recursos Externos & 1,91 & 0,10 & 1,41 \\
Recursos FTRA / Banco da Terra & 1,11 & 0,00 & 0,8 \\
Recursos do Tesouro & 0,35 & 2,54 & 0,95 \\
Recursos de Governos Estaduais & 0,05 & 0,08 & 0,06 \\
Recursos de Outras Fontes & 0,01 & 0,03 & 0,01 \\
\hline
\end{tabular}

Fonte: Anuário Estatístico do Crédito Rural - 2006

Por tudo que foi exposto, percebe-se que os créditos destinados à agropecuária e ao setor rural apresentam características específicas entre as operações do Sistema Financeiro Nacional. A quase totalidade dos financiamentos é realizada de acordo com as normas estabelecidas pelo Conselho Monetário Nacional; os bancos oficiais, principalmente o Banco do Brasil, canalizam a maior parte dos empréstimos e as fontes dos recursos são, em grande parte, de parcela obrigatória de depósitos bancários ou de repasses de fundos oficiais. A seção seguinte trata de apresentar a justificativa teórica para a intervenção estatal no mercado de crédito e a legislação que discorre sobre as exigibilidades do crédito rural. 


\subsection{Justificativas para a intervenção governamental no mercado de crédito rural}

Argumenta-se que a presença estatal no setor bancário justifica-se por falhas de mercado e pela necessidade de se cumprir funções de desenvolvimento. As falhas ligadas a assimetrias informacionais geram resultados sub-ótimos do ponto de vista social, com quantidades e preços diferentes daqueles que seriam os desejáveis em termos de bem-estar e podem resultar no sub-provimento de crédito a certos segmentos econômicos. (COSTA; NAKANE, 2005).

É neste contexto que surgem as justificativas teóricas para a intervenção governamental no mercado de crédito. Segundo o ponto de vista favorável às intervenções, as ações do governo devem ser orientadas no sentido de corrigir as falhas de mercado, gerando oportunidades de investimento para aqueles setores que, embora sejam considerados prioritários, encontram dificuldades no acesso ao crédito. As proposições habituais a favor da intervenção estatal no setor bancário podem ser classificadas, em termos gerais, dentro de quatro grupos (MICCO; PANIZZA, 2005):

i. Dar segurança e solidez ao sistema bancário - Os bancos são instituições inerentemente frágeis e, no caso de uma falência generalizada, as externalidades negativas são enormes. Além de atuarem como intermediários de crédito, os bancos representam a fonte de respaldo de liquidez para todas as demais instituições e são um importante canal de transmissão da política monetária.

ii. Mitigar falhas de mercado devido à assimetria informacional - $\mathrm{O}$ setor financeiro em geral e o setor bancário em particular são setores que fazem uso intensivo de informação. A assimetria informacional pode conduzir ao racionamento de crédito, situação na qual bons projetos podem não receber financiamento suficiente devido à falta de informação verificável.

iii. Financiar projetos socialmente valiosos, mas não viáveis financeiramente Investidores privados podem ter incentivos limitados a financiar projetos que produzem externalidades positivas. Nesse caso, a intervenção estatal se justifica para compensar imperfeições de mercado que geram financiamento insuficiente de projetos socialmente importantes, porém pouco atrativos financeiramente.

iv. Promover o desenvolvimento financeiro e proporcionar serviços bancários acessíveis para todos - Bancos privados, quando agem sem a intervenção governamental, podem decidir que não é rentável abrir sucursais em zonas rurais ou periféricas. Baseando-se 
na crença de que o acesso a serviços bancários pode fomentar o desenvolvimento financeiro e gerar externalidades positivas sobre o crescimento e a redução da pobreza, a intervenção governamental se justifica.

O ponto agora é entender porque a intervenção governamental é tão intensa no mercado de crédito rural. Por que se distingue o financiamento agrícola do crédito oferecido a outras categorias? Em que difere a atividade rural dos outros ramos de atividade? O que justifica a presença governamental e a concessão de crédito subsidiado ao setor agrícola?

O meio rural conta com algumas peculiaridades que agravam as dificuldades associadas ao seu financiamento. Primeiro, o caráter aleatório da rentabilidade das atividades agrícolas. Mais que qualquer outro setor de atividade, o setor rural é afetado pelas condições climáticas e pelo caráter cíclico ou incerto dos mercados. A baixa previsibilidade dos impactos do tempo, pestes e calamidades na produção associada à natureza sazonal das safras e aos períodos relativamente longos entre os processos de plantio e comercialização agravam o problema da incerteza com relação ao preço. Tudo isso tem efeitos diretos sobre os custos de transação, dado que esse padrão irregular implica maior dificuldade de monitoramento por parte da instituição financeira e menor disposição e capacidade de pagamento por parte do mutuário de crédito. ${ }^{11}$

Outro ponto peculiar à atividade agrícola é a baixa densidade populacional e a dispersão geográfica da clientela rural. Essa característica pode tornar consideráveis os custos da provisão de serviços financeiros. Sob a perspectiva do fornecedor de crédito, longas distâncias, meios de transporte inadequados e infra-estrutura insuficiente aumentam os custos de avaliação e monitoramento de empréstimos. E estes altos custos de transação aparecem também sob a perspectiva dos clientes rurais. O tempo e os recursos despendidos para apresentação das garantias e documentos necessários representam alto custo de oportunidade para o produtor e podem aumentar significativamente a taxa de juros efetiva, especialmente sobre pequenos empréstimos. Além de tudo isso, a população rural tende a ser mais pobre que a urbana, as operações se dão em pequena escala e formas tradicionais de colateral estão ausentes, o que limita a diversificação do risco e contribui para aumentar os custos de transação.

\footnotetext{
${ }^{11}$ Vale ressaltar que a incerteza e aleatoriedade das atividades agrícolas não necessariamente configuram uma justificativa à intervenção governamental no mercado de crédito. A questão apresentada expressa um ponto de vista, que pode ser contra-argumentado por meio da utilização de instrumentos privados de mercado. Nesse caso, a incerteza e aleatoriedade seriam compensadas através de mecanismos como seguro rural e mercados futuros.
} 
Besley (1994) adiciona o argumento de que as áreas rurais são, em geral, desprovidas de mercados complementares, o que acaba tornando ainda mais custoso o provimento de serviços financeiros. Observam-se deficiências em instituições complementares, como os mercados de seguros, por exemplo, que ajudariam a mitigar o problema da incerteza, e os sistemas de comunicação, que, quando bem desenvolvidos, ajudam a disseminar informações sobre os clientes, reduzindo problemas de default e custos de enforcement.

Somada a estas peculiaridades do setor rural que dificultam sua acessibilidade ao crédito, deve estar a percepção deste setor como essencial para a economia e o desenvolvimento do país. No Brasil, segundo Guilhoto et al (2006), o conjunto do agronegócio ${ }^{12}$ representou, em 2003, cerca de $30 \%$ do PIB e a agricultura familiar cerca de $10 \%$. Além de dinamizador da expansão produtiva, a agricultura desempenha outro papel de extrema importância para a economia brasileira: o de principal gerador de saldos comerciais para o País. O Gráfico 8 fornece uma idéia desta importância, já que a participação das exportações referentes ao agronegócio esteve por volta de $40 \%$ do total das exportações da balança comercial brasileira em todo o período apresentado.

\section{Gráfico 8 - Evolução anual da balança comercial brasileira e do agronegócio (US\$ bilhões)}

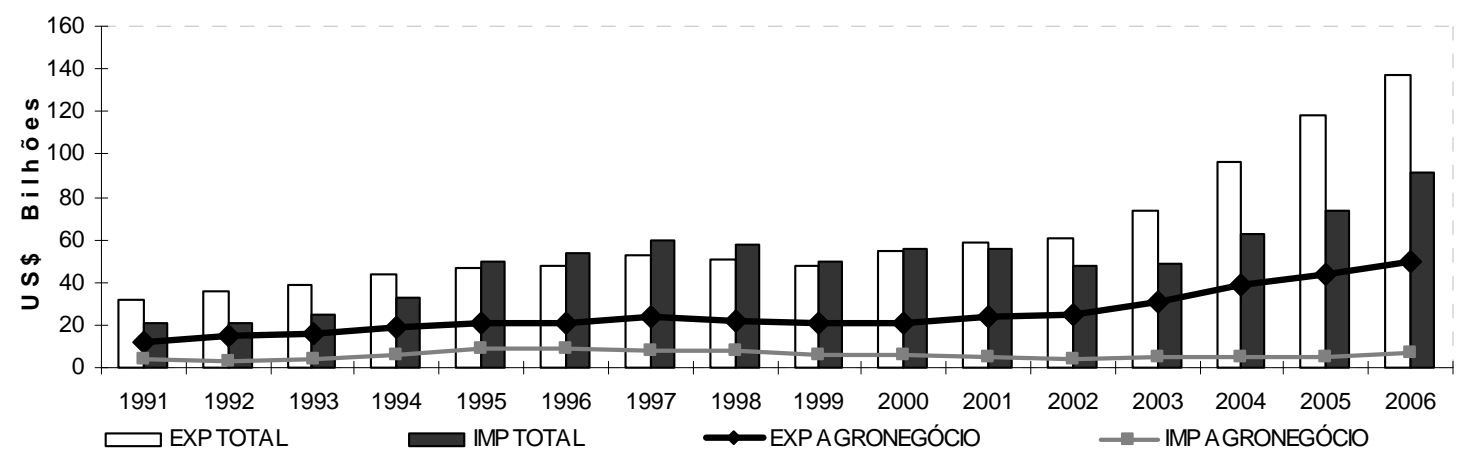

Fonte: AgroStat Brasil a partir de dados da SECEX/MDIC

Como foi visto na seção anterior, a maior parte dos recursos destinados ao crédito rural é proveniente de direcionamentos obrigatórios. A legislação que dispõe sobre as exigibilidades do crédito rural (MCR 6.2) ${ }^{13}$ determina que $25 \%$ dos depósitos à vista nas instituições financeiras devem ser aplicados nesta modalidade de crédito para os fins de custeio, investimento ou comercialização, a uma taxa de juros efetiva de $8,75 \%$ ao ano. Bancos

\footnotetext{
${ }^{12}$ Entende-se por agronegócio tudo o que envolve a cadeia produtiva da agricultura: a obtenção de insumos, a produção e renda gerada no processo de distribuição, e serviços que envolvem essa produção.

${ }^{3}$ Manual de Crédito Rural - Capítulo 6, Seção 2.
} 
comerciais que não cumprem essa exigência são obrigados a recolher os valores junto ao Banco Central, sem receber remuneração alguma.

Outra parcela significativa do programa de crédito rural subsidiado no Brasil é realizada com recursos de fundos e programas governamentais, em que os dispêndios com subsídios correspondem à despesa pública, com cobertura nas receitas do governo.

É claro que este processo de direcionamento alocativo de crédito não é neutro em seus resultados, mesmo porque ele nem pretende ser. O Estado direciona o crédito segundo prioridades políticas, buscando favorecer a canalização de recursos para setores específicos, mas este tipo de intervenção pode também provocar algum tipo de ineficiência alocativa com efeitos sobre as operações de crédito livre. Costa e Nakane (2005) identificam em seu estudo que o direcionamento de crédito para os setores rural e imobiliário gera um efeito de subsídio cruzado sobre as operações com recursos livres. Segundo os autores, em 2001, a componente de subsídio cruzado corresponde a 7,57\% do spread das operações livres, dos quais 5,02\% são relativos às operações obrigatórias de crédito imobiliário e $2,55 \%$ são referentes às operações com crédito rural obrigatório.

Tendo em vista a ampla intervenção governamental no mercado de crédito rural, faz-se necessário avaliar mais precisamente se o desempenho da atividade agrícola está realmente associado ao suprimento de crédito rural subsidiado.

É neste sentido que este trabalho tem implicações de política econômica. Será realizado um teste de causalidade para averiguar se efetivamente o crédito rural tem sido capaz de causar aumento no nível do PIB da agropecuária durante o período analisado. Caso os resultados não confirmem a direção da causalidade partindo do crédito para o PIB, a análise empírica não encontrará suportes para considerar o incentivo governamental e a concessão de crédito rural subsidiado como políticas bem sucedidas em seus objetivos de afetar o nível do produto agropecuário municipal. 


\subsection{Evolução histórica do crédito rural}

No período que compreende as décadas de 1950 e 1970, o Brasil passou por uma profunda alteração em sua estrutura demográfica, com aumento expressivo da população urbana e queda da população rural. O Gráfico 9 ilustra esta transformação mostrando, com dados censitários do IBGE, a estrutura da população brasileira, por situação do domicílio, desde 1940 até 2000.

\section{Gráfico 9 - População Urbana x População Rural}

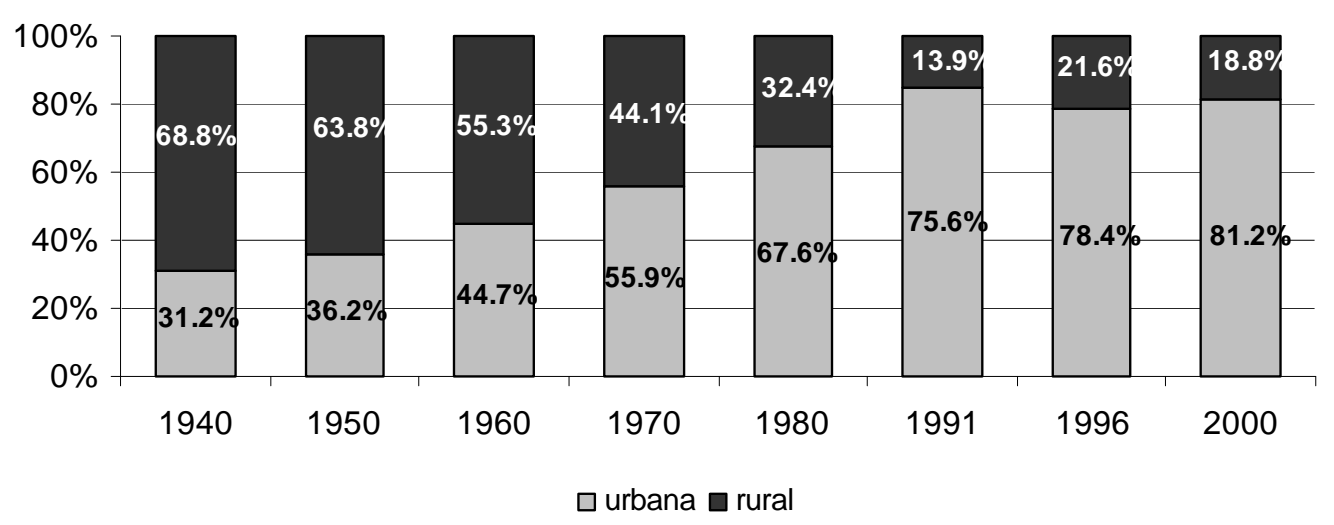

Fonte: IBGE - Dados históricos dos Censos 1940 a 1996 e Censo 2000

Segundo Sant `Anna e Ferreira (2006), uma vez que parte da mão-de-obra rural migrou para as cidades, a necessidade de produção de excedente na agricultura aumentou, o que, por sua vez, requereu um aumento considerável da produtividade agrícola a partir de 1960. Esta alteração na estrutura demográfica aliada à importância da produção rural na composição do produto fez ressaltar a necessidade de se instituir, com mais vigor, políticas governamentais de estímulo ao setor. O Gráfico 10, apresentado a seguir, ilustra a relevância da agropecuária na constituição do produto interno bruto, mostrando, em termos percentuais, a sua participação sobre o PIB total. Verifica-se que até 1965 a participação da agropecuária no PIB ultrapassava $15 \%$. 
Gráfico 10 - Produto Interno Bruto - Agropecuária (\%PIB)

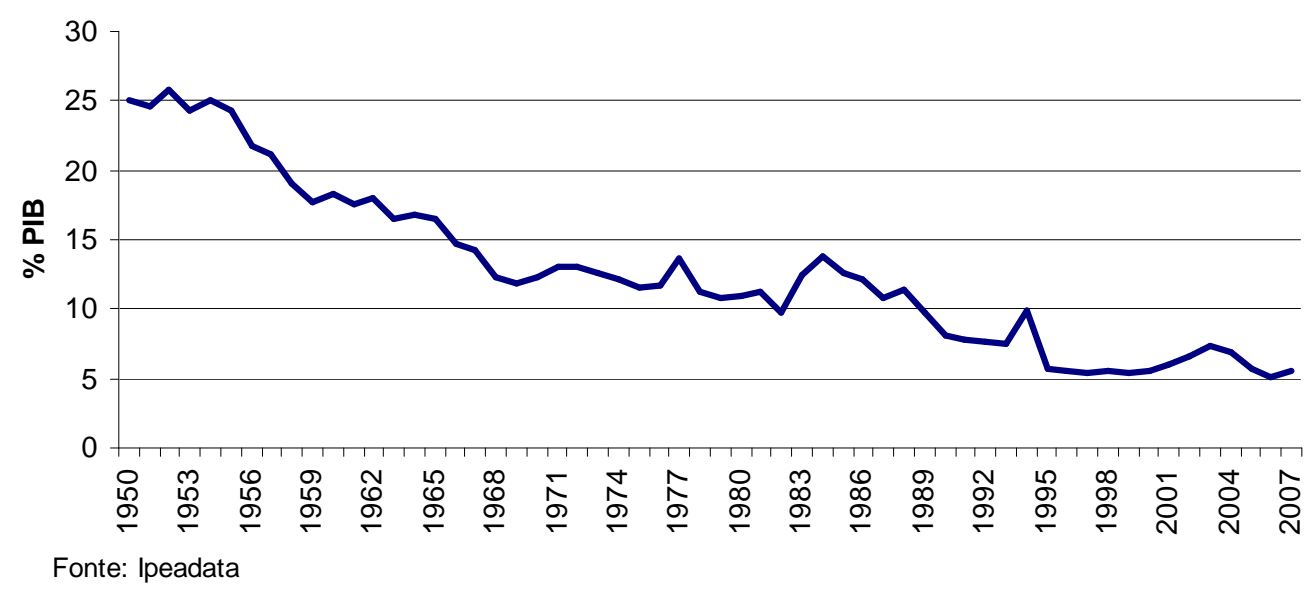

Com o intuito de fomentar a produção agropecuária, estruturou-se a política agrícola brasileira que, segundo Wedekin (2005), esteve baseada em dois elementos fundamentais: crédito rural e garantia de renda aos produtores. A Política de Garantia de Preços Mínimos (PGPM), criada em 1945, consolidava um conjunto de instrumentos de apoio a preços e garantia de renda ${ }^{14}$. Com relação às políticas de crédito preferencial para a agricultura, foi instituído, em 1965, o Sistema Nacional de Crédito Rural (SNCR), dentro do conjunto de reformas econômicas executadas pelo Programa de Ação Econômica do Governo (PAEG). Sua finalidade era fornecer créditos para investimento, custeio e comercialização da produção rural, tendo como público alvo, definido pela legislação, os produtores rurais e suas cooperativas.

Até meados da década de 80 , os empréstimos eram realizados a taxas de juros nominais fixas. Taxas estas que, em um contexto de aceleração da inflação, representavam, na prática, um forte subsídio implícito aos tomadores, os quais podiam captar a taxas reais negativas e aplicar paralelamente no mercado, auferindo substanciais ganhos financeiros. Houve forte expansão da oferta até o alcance de um pico em 1978, quando o volume de crédito rural equivalia a $85 \%$ do PIB agropecuário.

O Governo Federal, por meio do Banco do Brasil, provia a maior parte dos recursos destinados ao setor. O restante advinha de aplicações compulsórias a que os bancos comerciais ficaram sujeitos a partir da exigibilidade regulamentada pelo Conselho Monetário

\footnotetext{
${ }^{14}$ Os principais instrumentos da Política de Garantia de Preços Mínimos foram as Aquisições do Governo Federal (AGF), mecanismo de intervenção direta no mercado, com aquisição de produtos rurais pelo Governo e os Empréstimos do Governo Federal (EGF), que consistia na oferta de crédito para a estocagem e comercialização.
} 
Nacional, em 1967. No período 1965-85, 80\% do crédito rural advinham do Orçamento Monetário do governo, $12 \%$ provinham das exigibilidades bancárias e $8 \%$ de outras fontes. Os empréstimos financiados por emissão de moeda ou pela ampliação da dívida pública tinham como origem a Conta Movimento que o Banco do Brasil mantinha com o Banco Central e aportes de recursos do Tesouro Nacional.

O forte incentivo à tomada de recursos criou uma demanda que não condizia com a capacidade de expansão da agropecuária. "A demanda crescente por crédito rural gerava uma pressão contínua por novos recursos que, na prática, eram financiados com aumento da oferta monetária". (SANT'ANNA, FERREIRA; 2006) Tal procedimento acabou comprometendo a rolagem dos saldos devedores do programa e impactando positivamente a expansão monetária e o aumento do déficit fiscal. Por esta razão, iniciou-se, em meados da década de 1980, uma profunda transformação nos mecanismos de financiamento rural, em resposta à deterioração das contas públicas evidenciada pela crise fiscal que o governo atravessava.

Houve aumento das taxas de juros e introdução da correção monetária para os empréstimos, o que desestimulou a demanda adicional por recursos. No ano de 1986, foi extinta a Conta Movimento do Banco do Brasil, mecanismo que viabilizava as transferências de recursos do Orçamento Monetário para aplicação em crédito rural. Nesse contexto, o setor passou a buscar fontes alternativas de financiamento, frente à redução de recursos provenientes do Tesouro Nacional.

No final da década de 1980 e início da década de 1990, começaram a surgir novas fontes de financiamento e ampliou-se a participação do setor privado neste mercado. Como exemplo de novas fontes de financiamento, destacam-se a Caderneta de Poupança Rural do Banco do Brasil, criada em 1986, e os Fundos Constitucionais do Norte, Nordeste e Centro-Oeste, criados em 1989 com o objetivo de destinar recursos tributários para a aplicação em regiões menos desenvolvidas. Quanto aos mecanismos privados de financiamento, o destaque é a Cédula de Produto Rural (CPR), instituída em 1994, que é um título declaratório de entrega de produtos rurais, emitido pelo produtor. Este instrumento possibilitou ao agricultor antecipar a venda da produção com a finalidade de obter recursos para custear o plantio e se precaver parcialmente das incertezas relacionadas à comercialização. Em 2000, surgiu a CPR financeira, cuja liquidação é feita com um indicador de preço, sem envolver, portanto, a entrega física de mercadorias. 
Merece menção ainda a ampliação da participação do Banco Nacional de Desenvolvimento Econômico e Social (BNDES) entre as fontes de recursos. Durante os anos 1990, consolidouse a atuação desse banco em relação às atividades do setor agroindustrial. $\mathrm{O}$ período foi o mais significativo de sua história em termos de desembolsos para a agroindústria e em termos de programas específicos criados para diversas cadeias agroindustriais (GRIGOROVSKI et al, 2001). A Tabela 6 apresenta alguns dos programas do Governo Federal, administrados pelo BNDES, os quais contam com recursos do Fundo de Amparo ao Trabalhador (FAT) e são aplicados pelos agentes financeiros.

Tabela 6 - Programas agropecuários do Governo Federal administrados pelo BNDES

\begin{tabular}{lcl}
\hline \multicolumn{1}{c}{ Programa } & Ano & \multicolumn{1}{c}{ Objetivo } \\
\hline \hline PRONAF & 1995 & $\begin{array}{l}\text { Concessão de crédito a trabalhadores rurais, agricultores familiares, associações e } \\
\text { cooperativas, com o objetivo de aumentar a produção e o emprego no campo, melhor } \\
\text { distribuir a renda e reduzir o êxodo rural. }\end{array}$ \\
\hline Pró-Algodão & 1998 & Linha de crédito destinada ao financiamento da comercialização do algodão brasileiro. \\
\hline Prosolo & 1998 & $\begin{array}{l}\text { Financia a aquisição, o transporte e a aplicação de corretivos de solo, com o objetivo de } \\
\text { evitar a deterioração nos níveis de produtividade da agricultura no país. }\end{array}$ \\
\hline FINAME Especial & 1998 & $\begin{array}{l}\text { Financia a aquisição de máquinas e equipamentos para a atividade agropecuária } \\
\text { (tratores, colheitadeiras, implementos, plantadeiras, entre outros). }\end{array}$ \\
\hline $\begin{array}{l}\text { Implementos } \\
\text { Agrícolas }\end{array}$ & 1998 & $\begin{array}{l}\text { Financia a aquisição de implementos agrícolas novos e a recuperação de máquinas } \\
\text { tratores e equipamentos agrícolas }\end{array}$ \\
\hline Proleite & 1999 & $\begin{array}{l}\text { Financiamento de máquinas e equipamentos necessários à produção e estocagem do } \\
\text { leite cru (tanques de resfriamento, ordenhadeiras mecânicas, picadeiras, ensiladeiras, } \\
\text { entre outros). }\end{array}$ \\
\hline Moderfrota & $\begin{array}{l}\text { Financiar a aquisição de tratores agrícolas e implementos associados, colheitadeiras e } \\
\text { equipamentos para preparo, secagem e beneficiamento de café. }\end{array}$ \\
\hline Fonte:
\end{tabular}

Fonte: Grigorovski et al. (2001)

A partir dos anos 1990, o problema do endividamento da agricultura começou a tomar maiores dimensões. Esse problema se iniciou já na década de 1980, quando os empréstimos ao setor rural deixaram de ser concedidos a taxas de juros pré-fixadas e passaram a ser corrigidos por índices de preço, inicialmente, em 1982, pelo Índice Nacional de Preços ao Consumidor (INPC) e posteriormente, em 1989, pelo Índice de Preços ao Consumidor (IPC). O agravamento da situação deveu-se, em grande medida, ao descompasso entre a correção monetária do crédito rural e a evolução dos preços mínimos dos produtos agrícolas.

Em 1993, foi estabelecida a Comissão Parlamentar Mista e de Inquérito das Causas do Endividamento da Agricultura (CPMI), cujo objetivo era investigar as causas do 
endividamento, o custo dos financiamentos rurais e as condições de importação de alimentos entre 1990 e 1993. Em suma, podem ser apontadas como causas dos altos níveis de endividamento e inadimplência observados no período, a ruptura do modelo de crédito rural praticado na década de 1970 que culminou na descapitalização progressiva dos agricultores, potencializada pela alta das taxas de juros, correção monetária, valorização cambial e aumento da competição de produtos importados, que começavam a entrar com mais força no País.

Como resposta a essa situação, instaurou-se, em 1995, o início de um processo de renegociação das dívidas rurais, que consistiu na troca das dívidas dos produtores junto aos bancos por títulos emitidos pelo governo. Esse processo foi dividido em duas fases: a primeira, em 1995, foi direcionada à securitização de dívidas de valor inferior a R \$ 200 mil; a segunda, em 1998, destinada às dívidas acima de R \$ 200 mil. Atualmente, a dívida agrícola dos produtores com o setor financeiro está estimada em $\mathrm{R} \$ 87,5$ bilhões.

Wedekin (2005) resumiu os últimos 40 anos de política agrícola dividindo o período em três fases distintas: (i) de 1966 a 1985, "Intervenção Maciça" do governo, com expansão da oferta de crédito; (ii) de 1985 a 1994, "Crise da Dívida e Liberalização", caracterizada pela crise fiscal do governo, queda do volume de crédito concedido e choque de competição por produtos estrangeiros, e (iii) a partir de 1994, o período de "Inflação baixa", marcado pelo esgotamento dos mecanismos tradicionais de financiamento e securitização das dívidas agrícolas.

\subsection{Por que estudar o crédito rural?}

Parte significativa da literatura que contempla as relações entre crédito, sistema financeiro e desenvolvimento econômico, mesmo utilizando os mais variados tipos de dados e métodos, aponta para uma relação positiva entre sistema financeiro e desenvolvimento econômico, com a causalidade partindo do sistema financeiro para o desenvolvimento. O objetivo deste trabalho concentra-se, então, em verificar a validade desta tese para o nível municipal e para um instrumento financeiro específico: o crédito rural.

A restrição da análise ao crédito rural se justifica pelo fato desta modalidade de crédito ser, em sua maioria, direcionada e sofrer intervenção governamental com controle de quantidade e preço. Soma-se a este ponto o fato de que, pela própria natureza das áreas rurais, os custos de 
transação incorridos nas atividades financeiras rurais já são mais elevados e a dificuldade de obtenção de informações é maior do que o normalmente observado. Nestas circunstâncias, as funções do sistema financeiro de selecionar clientes, direcionar recursos para projetos mais rentáveis e produzir maior eficiência alocativa poderiam estar sendo distorcidas, fazendo com que o sistema financeiro não cumpra seu papel de impactar o desenvolvimento econômico por meio desta modalidade de crédito. 


\section{Dados e Métodos: Causalidade em Painel}

O terceiro capítulo desta dissertação estará dedicado à apresentação da base de dados e da metodologia de causalidade de Granger aplicada a um painel dinâmico. A primeira seção apresenta a fonte dos dados e as manipulações realizadas para a construção das variáveis. A segunda seção aplica à base de dados a metodologia de Análise Exploratória de Dados Espaciais (AEDE), na tentativa de captar os padrões de interação espacial das variáveis estudadas. Por fim, a última seção descreve a metodologia do teste de causalidade sugerida por Granger e Huang (1997) e sua adaptação, proposta por Rocha (2007). Os resultados das estimações econométricas serão apresentados no capítulo seguinte.

\subsection{Descrição dos dados}

Os dados de crédito rural disponíveis para este estudo foram extraídos dos Anuários Estatísticos do Crédito Rural, publicados pelo Banco Central do Brasil. Os dados são anuais e compreendem o período de 1999 a 2004. Utilizou-se o valor dos financiamentos concedidos a produtores e cooperativas, por município, para o total das atividades de agricultura e pecuária destinadas às finalidades de custeio, investimento e comercialização.

Já que a intenção é analisar a causalidade entre o volume de crédito rural concedido e o nível de produto da agropecuária, foi necessário buscar uma variável para representar o lado real da economia municipal. Por se tratar especificamente do crédito destinado ao setor rural, a variável selecionada foi o PIB da agropecuária. Utilizou-se, assim, o PIB municipal da agropecuária para os anos de 1999 a $2004^{15}$.

Uma das preocupações recorrentes neste trabalho é o interesse com o enfoque regional. Sendo assim, ao deflacionar os dados, utilizou-se como deflator o Índice de Preços ao Consumidor (IPCA), calculado pelo Instituto Brasileiro de Geografia e Estatística (IBGE) em dez regiões metropolitanas do Brasil: Belém, Belo Horizonte, Curitiba, Fortaleza, Porto Alegre, Recife, Rio de Janeiro, Salvador e São Paulo, além do município de Goiânia e o Distrito Federal. Dessa forma, em vez de utilizar um deflator nacional, os dados de crédito rural e PIB agropecuário para cada um dos municípios foram deflacionados utilizando-se o índice do IPCA da região metropolitana mais próxima daquele município.

\footnotetext{
${ }^{15}$ Embora estejam disponíveis os dados de PIB municipal também para o ano de 2005, estes foram calculados utilizando-se metodologia distinta da utilizada nos anos anteriores.
} 
A base de dados compreende, portanto, um painel não-balanceado cuja dimensão temporal é igual a 6 anos e as unidades seccionais são 5240 municípios brasileiros. Do total dos 5564 municípios do Brasil, foram excluídos aqueles que não apresentaram valores para as variáveis de interesse por 3 ou mais períodos.

\subsection{Análise Exploratória de Dados Espaciais}

A base de dados utilizada neste trabalho constitui-se em um caso típico da análise espacial. Conforme ressaltado por Almeida e Haddad (2004), a dependência espacial é facilmente verificável na agricultura, uma vez que os produtores agropecuários têm facilidade de observar como os seus vizinhos estão produzindo, que tipo de tecnologias ou inovações estão adotando etc. Ademais, as culturas agropecuárias dependem de recursos naturais que são, por definição, concentrados no espaço geográfico. Faz sentido pensar, por exemplo, que a definição do que será cultivado em cada território depende do tipo de solo, clima e chuvas da região, o que, por sua vez, não corresponde às fronteiras municipais.

É com o objetivo de apreender os padrões de associação espacial apresentados pelas variáveis PIB da agropecuária e crédito rural que será realizada nesta seção uma Análise Exploratória de Dados Espaciais (AEDE). A AEDE utiliza ferramentas estatísticas para descrever a distribuição espacial, os padrões de associação no espaço, verificar a existência de clusters e identificar a presença de observações atípicas.

Para implementar a AEDE, é necessário impor alguma estrutura, a priori, à interação espacial. Como um resultado da dependência espacial, o que é observado em um ponto no espaço é, em parte, determinado pelo que ocorre no resto do sistema. Esse processo de interação espacial pode ser ilustrado de maneira geral como: $y_{i}=f\left(y_{1}, y_{2}, \ldots, y_{n}\right)$. Ou seja, cada observação de uma variável $y$ em uma unidade espacial $i$ está relacionada com os valores desta variável $y$ em todas as outras localidades do sistema.

Tomando como base esta especificação geral, torna-se necessário impor alguma estrutura à relação funcional representada pela função $f($.). Esta estrutura será delineada a partir da utilização de uma matriz de pesos espaciais $(W)$, que definirá, em termos gerais, o "conjunto de vizinhos" de cada unidade espacial. São diversas as especificações sugeridas para a matriz $W$, mas, de maneira geral, há o consenso de que $W$ seja uma matriz positiva e que cada um de seus elementos $w_{i j}$ expresse a força da interação entre a localidade $i$ e a localidade $j$. Por 
convenção, os elementos da diagonal $w_{i i}$ são iguais a zero e os pesos espaciais são normalizados de maneira que a soma dos elementos de cada linha seja igual a 1. Este processo de normalização facilita a interpretação dos coeficientes do modelo já que a matriz $W$, assim estabelecida, faz uma média ponderada das variáveis de acordo com os pesos espaciais que estabelece $^{16}$.

A matriz de pesos espaciais, $W$, utilizada neste trabalho estabelece vizinhança como uma noção de distância. Utiliza-se, então, o inverso da distância euclidiana entre os centróides dos municípios como medida de vizinhança. Dessa forma, quanto menor for a distância entre a localidade $i$ e a localidade $j$, maior será o peso espacial correspondente a esta dupla de localidades, o que significa que $j$ terá maior força de influência sobre $i$ do que teriam outras unidades espaciais mais distantes.

Antes de iniciar a implementação do ferramental estatístico da AEDE, apresentamos, a seguir, mapas que caracterizam a distribuição regional do PIB da agropecuária e do crédito rural. Os Mapas A e C da Figura 1 mostram a distribuição regional das variáveis no ano de 2004, enquanto os Mapas B e D mostram o crescimento destas variáveis ao longo do período 19992004.

Analisando os mapas, é possível constatar que as variáveis PIB da agropecuária e crédito rural apresentam distribuição espacial semelhante, com maior concentração na região centro-sul do país (região mais escura do mapa). Quanto ao crescimento destas variáveis no período 19992004, este se deu com maior ênfase na região centro-oeste do país, no caso do PIB da agropecuária, e de forma mais difusa, no caso do crédito rural. Os padrões de concentração sugeridos pelos mapas devem ser confirmados por meio de testes formais, os quais serão apresentados nas sub-seções 3.2.1 e 3.2.2.

${ }^{16}$ A operação de normalização da matriz $W$ pode ser descrita formalmente como: $w_{N}(i, j)=\frac{w(i, j)}{\sum_{j} w(i . j)}$, em que $W_{N}$ é a matriz de pesos espaciais normalizada. 


\section{FIGURA 1}

Mapa A: PIB da Agropecuária (2004)

Mapa B: Evolução do PIB da Agropecuária
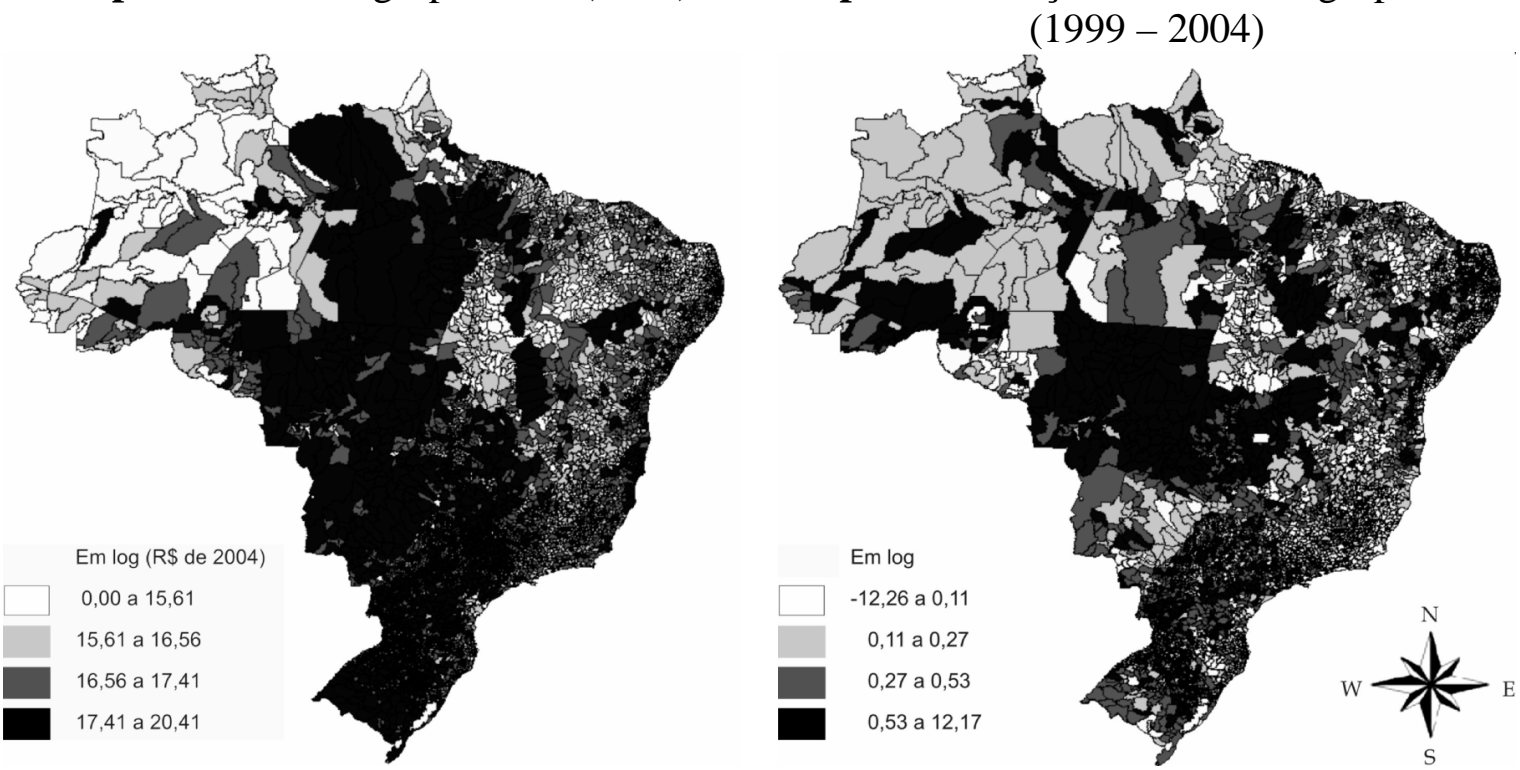

Fonte: Elaboração própria a partir de dados do IBGE

Mapa C: Crédito Rural (2004)

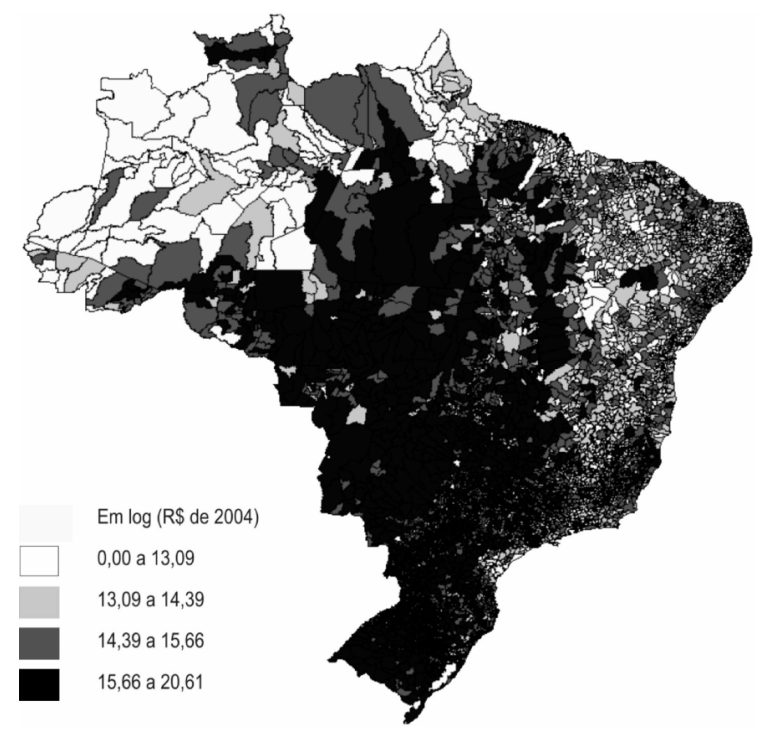

Mapa D: Evolução do Crédito Rural $(1999-2004)$

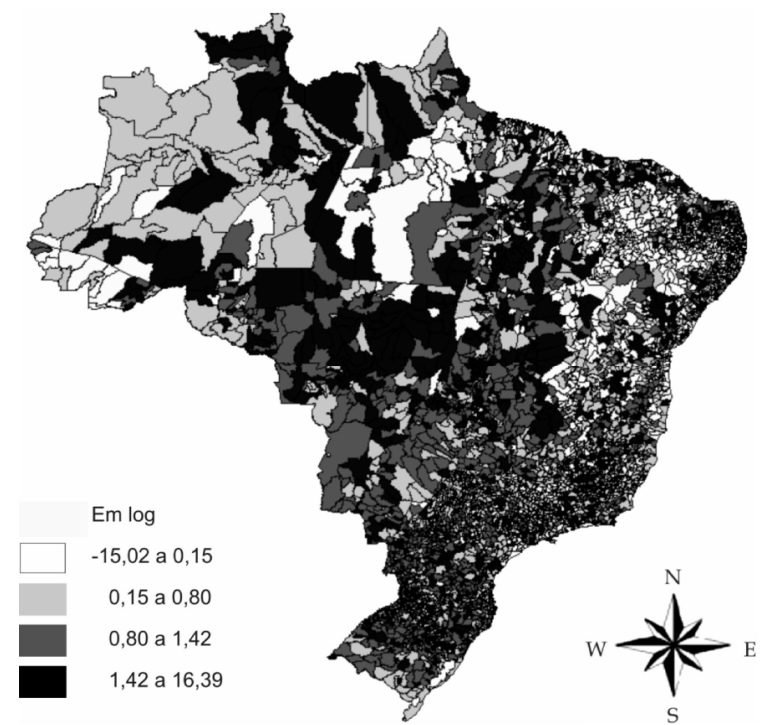

Fonte: Elaboração própria a partir de dados do Banco Central do Brasil 


\subsubsection{Autocorrelação espacial global}

O primeiro passo em uma análise exploratória espacial deve ser a verificação de autocorrelação espacial global. Mais especificamente, o conceito de autocorrelação espacial mensura em que medida o valor de uma variável observada em uma dada unidade geográfica apresenta correlação sistemática (não aleatória) com o valor da mesma variável observada nas localidades vizinhas. (RIGOTTI, VASCONCELOS; 2005)

A estatística $I$ de Moran é um dos instrumentos utilizados para detectar a autocorrelação espacial. Esta estatística fornece o grau de associação linear entre os vetores de valores observados de uma variável e a média ponderada dos valores da vizinhança, sob a hipótese nula de ausência de autocorrelação. Formalmente, a estatística $I$ de Moran é descrita por:

$I=\frac{n}{\sum_{i} \sum_{j} w_{i j}} \frac{\sum_{i} \sum_{j} w_{i j}\left(y_{i}-\bar{y}\right)\left(y_{j}-\bar{y}\right)}{\sum_{j}\left(y_{i}-\bar{y}\right)^{2}}$

em que $n$ é o número de localidades, $y_{i}$ é o valor da variável de interesse na localidade $i, \bar{y}$ é o valor médio da variável e $w_{i j}$ é o peso espacial para o par de localidades $(i, j)$.

A estatística $I$ de Moran tem o valor esperado de [-1/(n-1)], de maneira que valores iguais a esta esperança ou que estejam dentro dos limites de significância indicam aleatoriedade espacial. Valores de $I$ maiores que o valor esperado indicam autocorrelação positiva e valores menores indicam autocorrelação negativa. Assim como os demais indicadores de autocorrelação, a estatística $I$ de Moran também se situa no intervalo $[-1,1]$.

As tabelas 7 e 8 apresentam as estatísticas $I$ de Moran calculadas para as variáveis PIB da agropecuária e crédito rural em todos os anos da amostra. 
Tabela 7 - Índice de Moran - PIB da Agropecuária

\begin{tabular}{c|c|c|c|c}
\hline \multicolumn{5}{c}{ Variável: PIB da Agropecuária } \\
W: Matriz Distância Euclidiana \\
\hline Ano & $\begin{array}{c}\text { Índice de } \\
\text { Moran }\end{array}$ & Média & $\begin{array}{c}\text { Desvio } \\
\text { Padrão }\end{array}$ & p-value * \\
\hline \hline 1999 & 0,1560 & $-0,0002$ & 0,0012 & 0,0010 \\
\hline 2000 & 0,1453 & $-0,0002$ & 0,0012 & 0,0010 \\
\hline 2001 & 0,1493 & $-0,0002$ & 0,0011 & 0,0010 \\
\hline 2002 & 0,1457 & $-0,0002$ & 0,0011 & 0,0010 \\
\hline 2003 & 0,1647 & $-0,0002$ & 0,0012 & 0,0010 \\
\hline 2004 & 0,1657 & $-0,0002$ & 0,0013 & 0,0010 \\
\hline * Pseudo-significância obtida com base em 999 permutações
\end{tabular}

Tabela 8 - Índice de Moran - Crédito Rural

\begin{tabular}{c|c|c|c|c}
\hline \multicolumn{5}{c}{ Variável: Crédito Rural } \\
W: Matriz Distância Euclidiana \\
\hline Ano & $\begin{array}{c}\text { Índice de } \\
\text { Moran }\end{array}$ & Média & $\begin{array}{c}\text { Desvio } \\
\text { Padrão }\end{array}$ & $p$-value* \\
\hline \hline 1999 & 0,0583 & $-0,0002$ & 0,0011 & 0,0010 \\
\hline 2000 & 0,0727 & $-0,0002$ & 0,0011 & 0,0010 \\
\hline 2001 & 0,0630 & $-0,0002$ & 0,0012 & 0,0010 \\
\hline 2002 & 0,0648 & $-0,0002$ & 0,0011 & 0,0010 \\
\hline 2003 & 0,0812 & $-0,0002$ & 0,0012 & 0,0010 \\
\hline 2004 & 0,0758 & $-0,0002$ & 0,0012 & 0,0010 \\
\hline
\end{tabular}

* Pseudo-significância obtida com base em 999 permutações

A análise dos resultados dispostos nas Tabelas 7 e 8 leva à conclusão de que existe autocorrelação global positiva e significante nas variáveis PIB da agropecuária e crédito rural em todos os anos da amostra, sendo que esta autocorrelação mostra-se mais forte na variável PIB da agropecuária. Isso significa que municípios com elevada produção agropecuária são vizinhos de municípios que também apresentam elevado PIB da agropecuária, ao passo que municípios com baixo PIB estão cercados outros municípios na mesma situação. Esta constatação está, muito provavelmente, relacionada aos já citados aspectos geográficos dos recursos naturais, que são concentrados em um espaço que não corresponde às fronteiras municipais. 


\subsubsection{Autocorrelação espacial local}

Indicadores globais de autocorrelação espacial, como o Índice de Moran, fornecem um único valor como medida de associação espacial para todo o conjunto de dados, o que é útil para caracterizar o padrão espacial da região como um todo. Entretanto, quando se tem uma situação tal como é a do presente estudo, que lida com um grande número de municípios em uma área de grande extensão territorial, é muito provável que ocorram diferentes regimes de associação espacial, surgindo locais em que a dependência espacial não é significante e outros onde ela é muito pronunciada. (RIGOTTI, 2007)

Anselin (1995) sugeriu os indicadores locais de autocorrelação espacial, conhecidos como "LISA" - Local Indicators of Spatial Correlation, ${ }^{17}$ para medir a hipótese nula de ausência de autocorrelação espacial local. Esses indicadores comparam os valores da variável de interesse em cada localidade específica com os valores de sua vizinhança, buscando-se testar a presença de diferenças espaciais, em vez de assumir que estas diferenças não existem. A versão local da estatística $I$ de Moran, para cada localidade $i$, pode ser descrita por:

$I_{i}=z_{i} \sum_{j} w_{i j} z_{j}$

em que $z_{i}$ e $z_{j}$ são as variáveis em desvios da média, $w_{i j}$ é o peso espacial para o par de localidades $(i, j)$ e o somatório em $j$ é tal que somente os valores do conjunto vizinho de $i$ são considerados.

Seguindo o procedimento iniciado pela análise da autocorrelação global, este estudo partirá para a análise da versão local da estatística $I$ de Moran. Essa estatística permite a decomposição do padrão de autocorrelação espacial em quatro categorias: "alto-alto", "baixobaixo", "alto-baixo" e "baixo-alto". As duas primeiras categorias implicam autocorrelação positiva, o que significa que uma localidade que apresenta valores acima (abaixo) da média para um determinado atributo, estará rodeado por vizinhos que também apresentam valores acima (abaixo) da média para este mesmo atributo. Já as duas últimas categorias implicam autocorrelação negativa, que ocorre quando um município com valor alto (baixo) para determinada variável é vizinho de municípios com valores baixos (altos) para esta mesma variável.

\footnotetext{
${ }^{17}$ Indicadores locais de autocorrelação espacial podem ser obtidos em Anselin (1995).
} 
Os padrões locais de autocorrelação espacial para as variáveis PIB da agropecuária e crédito rural no ano de 2004 estão apresentados na Figura 2, a seguir, para um nível de significância de 5\%, ou seja, clusters persistentes até esse nível aparecem nos mapas. Os Mapas A e C mostram o nível de significância em cada região e os Mapas B e D apresentam os clusters espaciais.

Os mapas fornecem claras evidências de agrupamento espacial. Existem três clusters bem definidos: dois caracterizados pela categoria "baixo-baixo", abrangendo estados das regiões Norte, Nordeste e parte da região Sudeste e um caracterizado pelo regime "alto-alto", abrangendo toda a região Sul do país e parte das regiões Centro-Oeste e Norte. Nas regiões que intermedeiam estes clusters (parte branca do mapa) não foi identificado padrão espacial significante.

As ferramentas de Análise Exploratória de Dados Espaciais possibilitaram concluir que, em geral, municípios com elevado PIB da agropecuária e crédito rural são vizinhos de outros municípios na mesma situação e municípios com baixo nível de produto e crédito também são vizinhos de outros com as mesmas características. Em suma, foi possível confirmar a presença de dependência espacial nas variáveis estudadas, tanto global como localmente. 


\section{FIGURA 2}
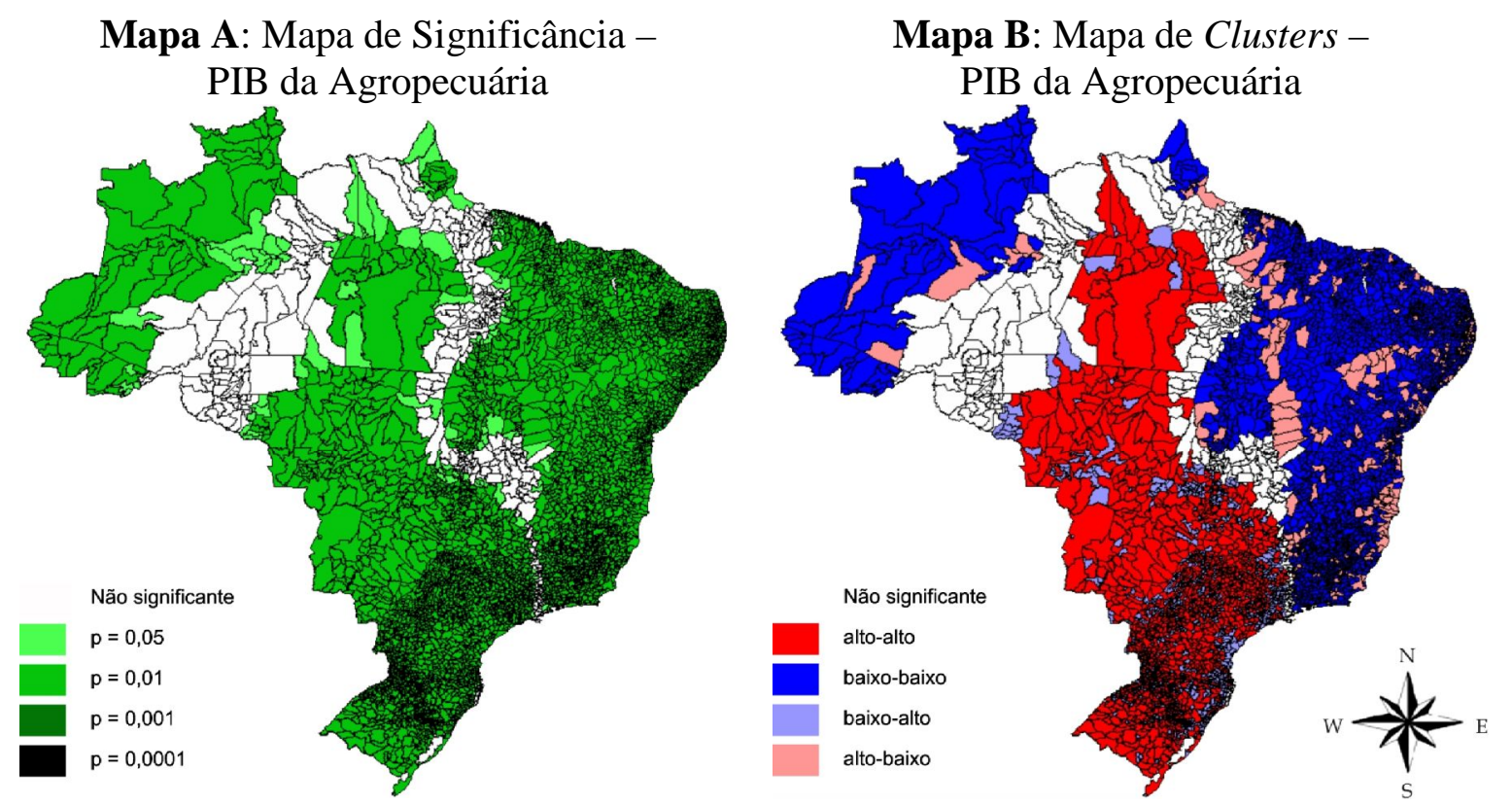

Fonte: Elaboração própria a partir de dados do IBGE

Mapa C: Mapa de Significância Crédito Rural

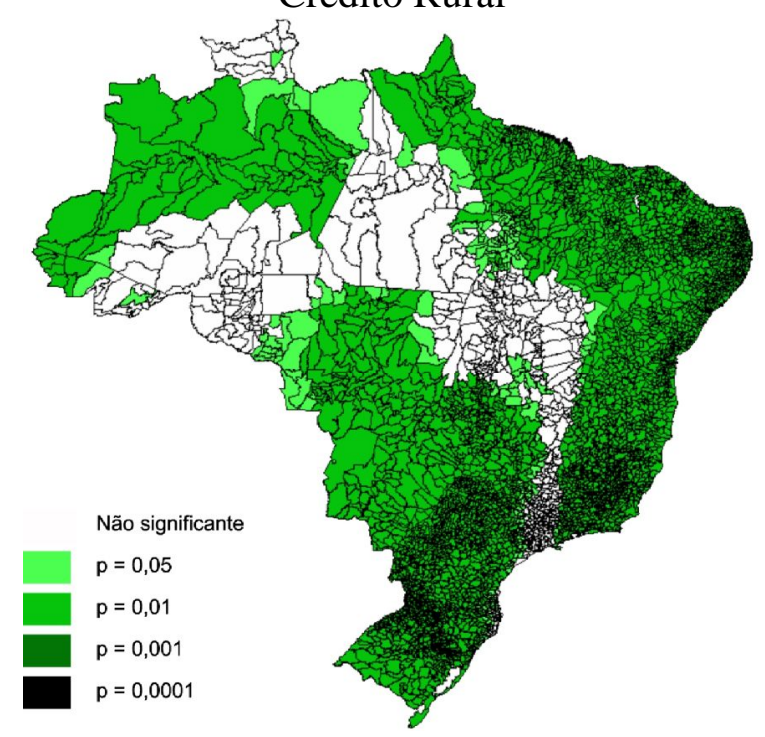

Mapa D: Mapa de Clusters Crédito Rural

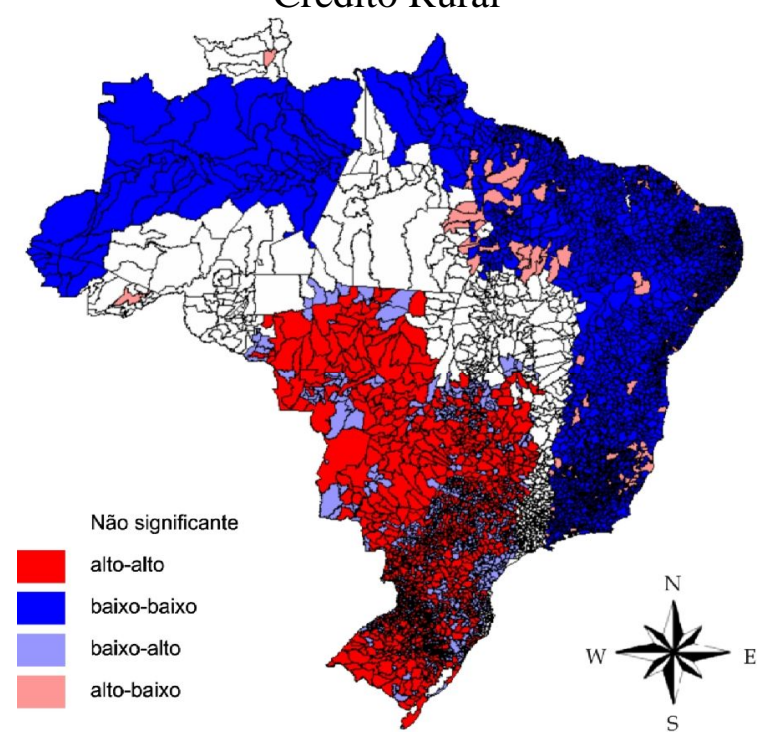

Fonte: Elaboração própria a partir de dados do Banco Central do Brasil 


\subsection{Metodologia Econométrica}

A metodologia econométrica utilizada neste trabalho segue as proposições de Granger e Huang (1997) que adaptam o conceito original de Granger (1969) para que este possa ser aplicado ao caso de um painel de dados. Implementou-se ainda uma extensão a esta metodologia proposta por Rocha (2007).

\subsubsection{Metodologia de Granger e Huang (1997)}

Na formulação de um modelo econométrico, três são as principais razões que podem levar à endogeneidade de uma variável explicativa e estimação inconsistente dos parâmetros: omissão de variável relevante, erros de medida e simultaneidade, ou causalidade reversa. (WOOLDRIDGE, 2002) Quando um destes problemas está presente, as estimativas obtidas por mínimos quadrados ordinários mostram-se viesadas e inconsistentes.

O problema que iremos investigar aqui está relacionado à questão da causalidade reversa, que surge quando uma variável explicativa $x$ é parcialmente determinada como função da variável dependente $y$.

É o que ocorre com as variáveis crédito rural e PIB da agropecuária. Como argumentos teóricos para a investigação de causalidade entre estas variáveis, pode-se imaginar que crédito causa PIB na medida em que mais crédito é capaz de alavancar a produção, incentivar a compra de máquinas e equipamentos que aumentam a produtividade e a aplicação de inovações ao processo de produção. Em contrapartida, pode-se argumentar que PIB causa crédito, já que regiões que apresentam maior renda derivada da agropecuária têm maior capacidade de apresentar as garantias requeridas e, portanto, atraem para si maior volume de crédito.

Em geral, testes de causalidade são realizados em um contexto de séries temporais. O estudo clássico de Granger (1969) estabeleceu um método para testar a direção de causalidade em modelos deste tipo. Dizemos que uma variável $\mathrm{X}$ causa outra variável $\mathrm{Y}$ quando "we are better to predict $Y$ using all available information than if the information apart from $X$ had been used" (GRANGER, 1969). Ou seja, se a inclusão de valores passados de X em uma regressão de $\mathrm{Y}$ em seus próprios valores defasados e outras variáveis explicativas contribui para melhorar a previsão da variável Y, dizemos que X Granger-causa Y. A causalidade bi- 
direcional irá ocorrer se valores passados de $\mathrm{X}$ são úteis para a previsão de $\mathrm{Y}$, assim como os valores passados de Y melhoram, por sua vez, a previsão de X.

Mais formalmente, para que X cause Y no sentido de Granger, o erro de previsão do modelo que inclui $\mathrm{X}$ deve ser menor que o erro do modelo que inclui apenas os valores defasados de Y:

$y_{t}-E\left(y_{t} / y_{t-1}, \ldots, y_{t-m}, x_{t-1}, \ldots, x_{t-n}\right)<y_{t}-E\left(y_{t} / y_{t-1}, \ldots, y_{t-m}\right)$,

em que $E($.$) é o operador de esperança condicionada.$

Embora o conceito original de Granger seja simples e facilmente testável, a aplicação desta metodologia, usualmente utilizada em um contexto de séries temporais, ao caso de um painel de dados não é trivial devido à impossibilidade de se aplicar os conceitos usuais de séries temporais a um painel cuja dimensão temporal é curta.

Outro ponto que traz uma complicação adicional ao teste é que a inclusão, em um painel, de valores defasados da variável dependente como variáveis explicativas, gera estimadores inconsistentes e viesados, especialmente em painéis curtos, em que a dimensão cross-section $(N)$ é muito maior do que a dimensão temporal (T). (HSIAO, 1993)

A inconsistência ocorre porque a eliminação do efeito fixo, via diferenciação, no processo de estimação dos parâmetros, cria correlação entre as variáveis explicativas e o termo de erro do modelo dinâmico. Para solucionar o problema, Arellano e Bond (1991) propuseram a utilização das próprias variáveis explicativas defasadas como instrumentos para as diferenças, com a aplicação da técnica de Momentos Generalizados para a estimação.

Como ilustração ao modelo proposto por Arellano e Bond (1991), assuma que existam $N$ unidades seccionais, observadas ao longo de $T$ períodos de tempo. Seja $i$ o índice para as observações de cross-section e $t$ o indexador do tempo. Assuma ainda a presença de um efeito específico $\theta_{i}$ para a $i$-ésima unidade de cross-section. O modelo pode ser representado por:

$y_{i t}=\alpha_{0}+\sum_{e=1}^{m} \beta_{e} y_{i t-e}+\sum_{k=1}^{n} \gamma_{k} x_{i t-k}+\theta_{i}+u_{i t}$ 
em que $m$ e $n$ são as defasagens de extensão suficiente para tornar o termo de erro $u_{i t}$ um ruído branco. Tirando a primeira diferença de (2) para eliminar o efeito não-observado, tem-se:

$$
\Delta y_{i t}=\sum_{e=1}^{m} \beta_{e} \Delta y_{i t-e}+\sum_{k=1}^{n} \gamma_{k} \Delta x_{i t-k}+\Delta u_{i t}
$$

Nesse ponto, observamos correlação entre o termo de erro e a variável dependente defasada. A sugestão de Arellano e Bond (1991) é que se utilizem os valores defasados das variáveis em nível como instrumentos para as diferenças. No caso, por exemplo, de $\Delta y_{i t-1}=\left(y_{i t-1}-y_{i t-2}\right)$, verificamos que esta variável está claramente correlacionada com $\left(u_{i t}-u_{i t-1}\right)$ e pode ser instrumentalizada pela variável defasada em nível, $y_{i t-2}$.

No modelo que pretendemos estimar neste estudo, temos como variável dependente o PIB da agropecuária e como variável independente o crédito rural. Nessa situação, além do problema da variável dependente defasada, há ainda que se levar em consideração o fato da variável explicativa, crédito rural, ser potencialmente endógena. A metodologia proposta por Arellano e Bond (1991) também permite endogeneidade nos outros regressores e resolve o problema da mesma forma: instrumentalizando as diferenças pelas variáveis defasadas em nível.

Prosseguindo com a metodologia de Granger e Huang (1997) aplicada ao caso da causalidade entre crédito rural e PIB agropecuário, se desejamos avaliar se o crédito rural (cred) causa o PIB agropecuário (pib), devemos estimar duas equações: uma contendo cred como variável explicativa e outra contendo apenas os valores defasados de pib.

Dessa forma, devemos estimar:

$$
\begin{aligned}
& \text { i) } p_{i b}=\alpha_{0}+\sum_{e=1}^{m} \beta_{e} \text { pib }_{i t-e}+\sum_{k=1}^{n} \gamma_{k} \text { cred }_{i t-k}+\theta_{i}+u_{i t} \\
& \text { ii) } p i b_{i t}=\alpha_{0}+\sum_{e=1}^{m} \beta_{e} p_{i b}+\theta_{i t-e}+u_{i t}
\end{aligned}
$$

A idéia básica de causalidade está relacionada ao poder relativo destas equações em realizar previsões. Se cred for uma variável importante para explicar pib, então o poder de previsão de (4) deve ser superior ao poder de previsão de (5). 
Para realizar a comparação entre o poder de previsão das equações alternativas, é implementado o teste de soma-diferença que utiliza erros de previsão "fora-da-amostra"18. Considere $e_{j t}{ }^{(1)}$ e $e_{j t}{ }^{(2)}$ os erros de previsão "fora-da-amostra" das equações com e sem a variável $\mathrm{cred}$, respectivamente ${ }^{19}$. A hipótese nula do teste em questão é a de que a variância do erro de previsão da equação de regressão que inclui cred é maior ou igual à do modelo sem esta variável. Nesse caso, cred não Granger-causa pib, já que a inclusão de cred não contribuiu para melhorar a capacidade de previsão do modelo. Então,

$$
H_{0}: E\left[\left(e^{(1)}\right)^{2}\right] \geq E\left[\left(e^{(2)}\right)^{2}\right]
$$

Para realizar o procedimento de soma-diferença requerido para o teste da hipótese nula, defina:

$$
\begin{aligned}
& S \equiv \text { Soma }=e^{(1)}+e^{(2)} \\
& D \equiv \text { Diferença }=e^{(1)}-e^{(2)}
\end{aligned}
$$

Em seguida, testar $H_{0}$ é equivalente a testar a hipótese de que o coeficiente $b$ na regressão (7) é maior ou igual a zero.

$$
S_{j t}=a+b D_{j t}+u_{j t}
$$

Se for possível dizer que $b<0$, então $H_{0}$ será rejeitada e o modelo com a menor variância do erro de previsão deve ser aceito como sendo significativamente superior. Conforme mostra Rocha (2007), este resultado deriva dos seguintes passos:

\footnotetext{
${ }^{18}$ Segundo Weinhold e Reis (1999), no caso de um painel de dados, o ajuste e a correlação contemporânea "dentro da amostra" são muito elevados, já que estes podem ser provenientes da variabilidade tanto de crosssection como de séries temporais. Dessa forma, é preferível discriminar os modelos pela sua capacidade de previsão "fora da amostra".

19 A maneira de se obter erros de previsão "fora-da-amostra" é estimando cada um dos dois modelos, representados pelas equações (4) e (5), com a exclusão de uma observação de cross-section. Este processo é repetido para cada uma das unidades seccionais até que se forme um painel de erros de previsão. Formado o painel de erros de previsão, temos as variáveis requeridas para o teste soma-diferença.
} 
i) Partindo da equação do teste de soma-diferença, chega-se ao estimador da regressão simples.

$$
\hat{b}=\frac{\sum_{n=1}^{N}\left(D_{j t} \times S_{j t}\right)}{\sum_{n=1}^{N}\left(D_{j t}\right)^{2}}
$$

ii) De acordo com as definições de soma e diferença dos erros de previsão (7), tem-se:

$$
\hat{b}=\frac{\sum_{n=1}^{N}\left(e_{j t}{ }^{(1)}-e_{j t}{ }^{(2)}\right)\left(e_{j t}{ }^{(1)}+e_{j t}{ }^{(2)}\right)}{\sum_{n=1}^{N}\left(e_{j t}{ }^{(1)}-e_{j t}{ }^{(2)}\right)^{2}}
$$

iii) Manipulando algebricamente, chega-se a:

$$
\hat{b}=\frac{n\left\{E\left[\left(e_{j t}^{(1)}\right)^{2}\right]-E\left[\left(e_{j t}^{(2)}\right)^{2}\right]\right\}}{\sum_{n=1}^{N}\left(e_{j t}{ }^{(1)}-e_{j t}{ }^{(2)}\right)^{2}}
$$

Tendo em conta que $n$ e o denominador de (11) são sempre positivos, chega-se à conclusão de que quando $E\left[\left(e^{(1)}\right)^{2}\right] \geq E\left[\left(e^{(2)}\right)^{2}\right], \hat{b} \geq 0$. Ou seja, quando a variância do erro de previsão da equação que inclui cred como variável explicativa é maior ou igual à variância do erro de previsão do modelo contendo apenas a variável dependente defasada, o sinal do coeficiente $b$ estimado na regressão de soma-diferença é maior ou igual a zero. Nesse caso, aceita-se a hipótese nula e conclui-se que cred não Granger-causa pib.

O teste deve ser complementado realizando-se os mesmos procedimentos na direção contrária, ou seja, considerando cred como variável dependente e pib como variável explicativa. Nessa situação, testamos a hipótese nula de que pib não Granger-causa cred.

A metodologia proposta por Granger e Huang (1997) se resume ao que foi apresentado acima. Entretanto, Rocha (2007) propõe uma extensão a este procedimento para que o teste se torne robusto às situações em que os erros de previsão são formados levando-se em consideração a constante e os efeitos específicos. Os erros de previsão derivados dos modelos (4) e (5) são formados da seguinte forma: 


$$
\begin{aligned}
& \hat{e}_{i t}^{(1)}=p i b_{i t}-\hat{\alpha}_{0}-\hat{\theta}_{i}-\sum_{e=1}^{m} \hat{\beta}_{e} p i b_{i t-e}+\sum_{k=1}^{n} \hat{\gamma}_{k} \operatorname{cred}_{i t-k} \\
& \hat{e}_{i t}^{(2)}=p i b_{i t}-\hat{\alpha}_{0}-\hat{\theta}_{i}-\sum_{e=1}^{m} \hat{\beta}_{e} p i b_{i t-e}
\end{aligned}
$$

Rocha (2007), ao propor um método robusto para o teste com os erros de previsão formados da maneira especificada acima, sugere que se definam os erros de previsão não condicionais na constante e no efeito fixo:

$$
\begin{aligned}
& \xi_{i t}^{(1)}=\hat{e}_{i t}^{(1)}+\alpha_{0}+\theta_{i} \\
& \xi_{i t}^{(2)}=\hat{e}_{i t}^{(2)}+\alpha_{0}+\theta_{i}
\end{aligned}
$$

Seguindo as proposições de Rocha (2007), a soma e a diferença dos erros de previsão tornamse:

$$
\begin{aligned}
& S_{i t}^{*}=\xi_{i t}^{(1)}+\xi_{i t}^{(2)}=S_{i t}-k_{i}, \text { em que } k_{i}=2\left(\alpha_{0}+\theta_{i}\right) \\
& D_{i t}^{*}=\xi_{i t}^{(1)}-\xi_{i t}^{(2)}=D_{i t}
\end{aligned}
$$

O teste soma-diferença, análogo ao (8), será, portanto:

$$
\begin{aligned}
& S_{i t}^{*}=a+b D_{i t}^{*}+u_{i t}, \text { ou seja }: \\
& S_{i t}=a+k_{i}+b D_{i t}+u_{i t}
\end{aligned}
$$

Da mesma forma, a intenção é testar o parâmetro $b$, porém desta vez existe um componente de efeito fixo na equação a ser estimada. Para que a estimação gere resultados consistentes, este parâmetro deve ser devidamente controlado por meio de uma regressão de primeiras diferenças que elimine o efeito fixo $k_{\mathrm{i}}$.

No capítulo 4, será realizada uma tentativa de associar as duas metodologias apresentadas. Iremos aplicar a metodologia de causalidade de Granger em painel levando em consideração as correlações espaciais por meio da inclusão de duas variáveis adicionais, Wpib e Wcred, as quais representam uma ponderação espacial das variáveis principais, pib e cred, e, portanto, a influência dos valores observados nas vizinhanças na determinação do valor das variáveis de interesse em cada localidade. 


\section{Resultados e Conclusões}

Neste capítulo serão apresentados os principais resultados das estimações realizadas. Além do modelo mais simples com apenas as duas variáveis principais, outros testes serão realizados, com a criação de uma variável espacial e regressões separadas por região geográfica. $\mathrm{O}$ objetivo dos testes adicionais é dar robustez aos resultados encontrados. O capítulo está dividido em duas seções: a primeira apresenta os resultados dos modelos estimados e a seção final sintetiza as principais conclusões.

\subsection{Resultados}

Inicialmente, será apresentado o resultado da regressão de soma-diferença (12) dos modelos incluindo apenas as duas variáveis principais, cred e pib, utilizando erros de previsão "forada-amostra". Os resultados estão expostos na Tabela 9 e diferem quanto ao número de defasagens utilizadas.

Para melhor entendimento da Tabela 9, convém esclarecer alguns pontos. A coluna "Modelo" explicita a dupla de equações geradora das séries de erros de previsão utilizados no teste de soma-diferença. Nesse caso, conforme mencionado no Capítulo 3, estimamos dois modelos, sendo que no Modelo I a variável dependente é pib e no Modelo II a variável dependente é cred. Cada um dos modelos irá gerar duas séries de erros de previsão. No caso do Modelo I, serão geradas as series de erros com e sem a variável cred e, no caso do Modelo II, serão geradas as séries de erros com e sem a variável pib. Tendo sido geradas as séries de erros de previsão, é realizado o teste de soma-diferença.

\section{Modelo I:}

$$
\begin{aligned}
& \text { i) } p_{i b}=\alpha_{0}+\sum_{e=1}^{m} \beta_{e} \text { pib }_{i t-e}+\sum_{k=1}^{n} \gamma_{k} \text { cred }_{i t-k}+\theta_{i}+u_{i t} \\
& \text { ii) } p i b_{i t}=\alpha_{0}+\sum_{e=1}^{m} \beta_{e} p i b_{i t-e}+\theta_{i}+u_{i t}
\end{aligned}
$$

\section{Modelo II:}

i) $\operatorname{cred}_{i t}=\alpha_{0}+\sum_{e=1}^{m} \beta_{e} \operatorname{cred}_{i t-e}+\sum_{k=1}^{n} \gamma_{k}$ pib $_{i t-k}+\theta_{i}+u_{i t}$

ii) cred $_{i t}=\alpha_{0}+\sum_{e=1}^{m} \beta_{e}$ cred $_{i t-e}+\theta_{i}+u_{i t}$ 
Tabela 9 - Resultado do teste soma-diferença para os modelos I e II

\begin{tabular}{|c|c|c|c|c|}
\hline Modelo & Hipótese Nula & Defasagens & $\begin{array}{c}\text { Estatística do } \\
\text { teste } \\
\text { soma-diferença }\end{array}$ & Conclusão \\
\hline \multirow{3}{*}{ I } & \multirow{3}{*}{$\begin{array}{c}\text { Crédito não Granger-causa } \\
\text { PIB }\end{array}$} & 1 & $\begin{array}{l}b=-19.191 \\
(0.000)\end{array}$ & Rejeita HO \\
\hline & & 2 & $\begin{array}{c}b=2.481 \\
(0.000)\end{array}$ & Não rejeita H0 \\
\hline & & 3 & $\begin{array}{c}b=0.563 \\
(0.000)\end{array}$ & Não rejeita H0 \\
\hline \multirow{3}{*}{ II } & \multirow{3}{*}{$\begin{array}{c}\text { PIB não Granger-causa } \\
\text { Crédito }\end{array}$} & 1 & $\begin{array}{l}b=-7.409 \\
(0.000)\end{array}$ & Rejeita H0 \\
\hline & & 2 & $\begin{array}{c}b=-3.899 \\
(0.000)\end{array}$ & Rejeita HO \\
\hline & & 3 & $\begin{array}{c}b=-0.733 \\
(0.000)\end{array}$ & Rejeita HO \\
\hline
\end{tabular}

p-valor entre parênteses

No modelo contendo uma defasagem, a conclusão inferida a partir dos resultados é a de que existe causalidade bi-direcional: crédito rural Granger-causa PIB da agropecuária e PIB da agropecuária Granger-causa crédito rural, haja vista o sinal negativo e significante do coeficiente $b$ na regressão de soma-diferença. Já nos modelos com duas e três defasagens, a conclusão é diferente. Nesses dois casos, há causalidade unidirecional, partindo do PIB para o crédito e a conclusão é de que crédito rural não Granger-causa PIB da agropecuária.

O próximo resultado a ser apresentado inclui duas variáveis explicativas adicionais aos Modelos $I$ e II. Trata-se de uma ponderação espacial das variáveis principais, cred e pib, utilizando a mesma matriz de pesos espaciais, $W$, apresentada na seção $3.2 .^{20}$ A inclusão das variáveis espaciais têm o objetivo de considerar o efeito das correlações espaciais na estimação. A seção 3.2 já demonstrou o fato de que existe autocorrelação espacial significante na amostra e, dessa maneira, justifica a inclusão das variáveis espaciais como controles adicionais importantes aos modelos. Assim, chamaremos de modelos $I I I$ e $I V$, as versões dos modelos $I$ e II incluindo as variáveis espaciais, Wpib e Wcred.

\footnotetext{
${ }^{20}$ Este procedimento segue as proposições do trabalho de Weinhold e Reis (1999).
} 


\section{Modelo III:}

i) $p i b_{i t}=\alpha_{0}+\sum_{e=1}^{m} \beta_{e} p i b_{i t-e}+\sum_{k=1}^{n} \gamma_{k}$ cred $_{i t-k}+\delta_{1} W_{i}$ pib $_{t-1}+\delta_{2} W_{i}$ cred $_{t-1}+\theta_{i}+u_{i t}$

ii) $p_{i b} b_{i t}=\alpha_{0}+\sum_{e=1}^{m} \beta_{e} p i b_{i t-e}+\delta_{1} W_{i} p i b_{t-1}+\delta_{2} W_{i} \operatorname{cred}_{t-1}+\theta_{i}+u_{i t}$

\section{Modelo IV:}

i) $\operatorname{cred}_{i t}=\alpha_{0}+\sum_{e=1}^{m} \beta_{e}$ cred $_{i t-e}+\sum_{k=1}^{n} \gamma_{k}$ pib $_{i t-k}+\delta_{1} W_{i}$ pib $_{t-1}+\delta_{2} W_{i}$ cred $_{t-1}+\theta_{i}+u_{i t}$

ii) $\operatorname{cred}_{i t}=\alpha_{0}+\sum_{e=1}^{m} \beta_{e} \operatorname{cred}_{i t-e}+\delta_{1} W_{i}$ pib $_{t-1}+\delta_{2} W_{i} \operatorname{cred}_{t-1}+\theta_{i}+u_{i t}$

em que $W_{i}$ é a linha correspondente ao município $i$ da matriz $W$ e $\operatorname{pib}_{t-1}$ e $\operatorname{cred}_{t-1}$ são os vetores de $p i b$ e cred no período $t-1$.

\section{Tabela 10 - Resultado do teste soma-diferença para os modelos III e IV}

\begin{tabular}{|c|c|c|c|c|}
\hline Modelo & Hipótese Nula & Defasagens & $\begin{array}{l}\text { Estatística do } \\
\text { teste } \\
\text { soma-diferença }\end{array}$ & Conclusão \\
\hline \multirow{3}{*}{ III } & \multirow{3}{*}{$\begin{array}{c}\text { Crédito não Granger-causa } \\
\text { PIB }\end{array}$} & 1 & $\begin{array}{c}b=0.489 \\
(0.000)\end{array}$ & Não rejeita $\mathrm{H}_{0}$ \\
\hline & & 2 & $\begin{array}{l}b=0.599 \\
(0.000)\end{array}$ & Não rejeita $\mathrm{H}_{0}$ \\
\hline & & 3 & $\begin{array}{l}b=0.916 \\
(0.000)\end{array}$ & Não rejeita $\mathrm{H}_{0}$ \\
\hline \multirow{3}{*}{ IV } & \multirow{3}{*}{$\begin{array}{c}\text { PIB não Granger-causa } \\
\text { Crédito }\end{array}$} & 1 & $\begin{array}{l}b=-5.838 \\
(0.000)\end{array}$ & Rejeita $\mathrm{H}_{0}$ \\
\hline & & 2 & $\begin{array}{l}b=-0.427 \\
(0.000)\end{array}$ & Rejeita $\mathrm{H}_{0}$ \\
\hline & & 3 & $\begin{array}{c}b=-2.136 \\
(0.000)\end{array}$ & Rejeita $\mathrm{H}_{0}$ \\
\hline
\end{tabular}

p-valor entre parênteses

Desta vez, independentemente do número de defasagens incluídas nos modelos, os testes foram unânimes em apontar causalidade unidirecional, partindo do PIB da agropecuária para o crédito rural. Novamente, não foi possível identificar causalidade no sentido de Granger partindo do crédito rural em direção ao PIB.

Tendo em conta a expressiva desigualdade regional observada no Brasil, notadamente no que diz respeito ao produto agropecuário e ao crédito rural, torna-se relevante confirmar a validade dos resultados obtidos em cada uma das regiões brasileiras. A tabela que se segue 
apresenta os resultados dos modelos que incluem as variáveis espaciais (Wpib e Wcred), estimados separadamente por região geográfica.

Observa-se que, com exceção da região Sul, o resultado encontrado foi igual ao resultado obtido para o Brasil, qual seja o de que crédito não Granger-causa PIB, ou de causalidade unidirecional, partindo do PIB para o crédito. Nas regiões Nordeste e Centro-Oeste, observouse causalidade bidirecional quando o modelo inclui apenas uma defasagem. Nos modelos com duas ou três defasagens, observou-se causalidade unidirecional, partindo do PIB da agropecuária para o crédito rural. Na região Sul, embora os sinais dos coeficientes $b$ nas regressões com duas e três defasagens, tendo crédito como variável dependente, sejam negativos, não rejeitamos a hipótese nula de que PIB não Granger-causa crédito já que estes coeficientes não se mostraram significantes, ao passo que o sinal negativo e significante das regressões que têm PIB como variável dependente leva à conclusão de que crédito rural Granger-causa PIB da agropecuária na região Sul.

Tabela 11 - Resultado do teste soma-diferença por região geográfica

\begin{tabular}{|c|c|c|c|c|c|c|}
\hline \multirow[b]{2}{*}{ Hipótese Nula } & \multirow[b]{2}{*}{ Defasagens } & \multicolumn{5}{|c|}{ Região } \\
\hline & & Norte & Nordeste & $\begin{array}{c}\text { Centro- } \\
\text { Oeste }\end{array}$ & Sudeste & Sul \\
\hline \multirow{3}{*}{$\begin{array}{c}\text { Crédito não } \\
\text { Granger-causa } \\
\text { PIB }\end{array}$} & 1 & $\begin{array}{c}b=4.096 \\
(0.000)\end{array}$ & $\begin{array}{c}b=-0.388 \\
(0.004)\end{array}$ & $\begin{array}{c}b=-0.167 \\
(0.002)\end{array}$ & $\begin{array}{c}b=1.001 \\
(0.000)\end{array}$ & $\begin{array}{c}b=-0.869 \\
(0.000)\end{array}$ \\
\hline & 2 & $\begin{array}{c}b=0.804 \\
(0.000)\end{array}$ & $\begin{array}{c}b=1.747 \\
(0.000)\end{array}$ & $\begin{array}{c}b=0.488 \\
(0.000)\end{array}$ & $\begin{array}{c}b=1.128 \\
(0.000)\end{array}$ & $\begin{array}{c}b=-0.887 \\
(0.000)\end{array}$ \\
\hline & 3 & $\begin{array}{c}b=1.612 \\
(0.000)\end{array}$ & $\begin{array}{c}b=0.949 \\
(0.000)\end{array}$ & $\begin{array}{c}b=0.674 \\
(0.000)\end{array}$ & $\begin{array}{c}b=0.911 \\
(0.000)\end{array}$ & $\begin{array}{c}b=-0.896 \\
(0.000)\end{array}$ \\
\hline \multirow{3}{*}{$\begin{array}{l}\text { PIB não } \\
\text { Granger-causa } \\
\text { Crédito }\end{array}$} & 1 & $\begin{array}{c}b=-4.469 \\
(0.000)\end{array}$ & $\begin{array}{c}b=-0.809 \\
(0.000)\end{array}$ & $\begin{array}{c}b=-0.933 \\
(0.000)\end{array}$ & $\begin{array}{c}b=-5.234 \\
(0.000)\end{array}$ & $\begin{array}{c}b=0.343 \\
(0.022)\end{array}$ \\
\hline & 2 & $\begin{array}{c}b=-1.233 \\
(0.000)\end{array}$ & $\begin{array}{c}b=-1.152 \\
(0.000)\end{array}$ & $\begin{array}{c}b=-0.446 \\
(0.000)\end{array}$ & $\begin{array}{c}b=-0.672 \\
(0.000)\end{array}$ & $\begin{array}{c}b=-0.152 \\
(0.384)\end{array}$ \\
\hline & 3 & $\begin{array}{c}b=-0.744 \\
(0.000)\end{array}$ & $\begin{array}{c}b=-0.567 \\
(0.000)\end{array}$ & $\begin{array}{c}b=-0.251 \\
(0.000)\end{array}$ & $\begin{array}{c}b=-4.407 \\
(0.000)\end{array}$ & $\begin{array}{c}b=-0.222 \\
(0.212)\end{array}$ \\
\hline
\end{tabular}

Tendo sido observada a causalidade de Granger do crédito rural para o PIB agropecuário na região Sul do país, vale questionar se seria possível verificar efeitos de externalidade para além do setor rural naquela região. Nesse sentido, os próximos resultados a serem apresentados na Tabela 12 são relativos a regressões que relacionam o crédito rural ao PIB do setor industrial, de serviços e total da região. 
Tabela 12 - Resultado do teste soma-diferença para a região Sul

\begin{tabular}{c|c|c|c|c}
\hline \multirow{2}{*}{ Hipótese Nula } & \multirow{2}{*}{ Defasagens } & \multicolumn{3}{|c}{ Região Sul } \\
\cline { 3 - 5 } & & PIB Industrial & $\begin{array}{c}\text { PIB de } \\
\text { Serviços }\end{array}$ & $\begin{array}{c}\text { PIB Total da } \\
\text { Região Sul }\end{array}$ \\
\hline \hline & 1 & $b=1.839$ & $b=-1.413$ & $b=2.107$ \\
Crédito não & $\cdots$ & $(0.000)$ & $(0.004)$ & $(0.000)$ \\
Granger-causa & 2 & $b=3.095$ & $b=0.461$ & $b=2.624$ \\
PIB & 3 & $(0.000)$ & $(0.105)$ & $(0.000)$ \\
& & $b=0.058$ & $b=0.230$ & $b=0.793$ \\
& & $(0.585)$ & $(0.001)$ & $(0.000)$ \\
\hline PIB não & 1 & $b=-1.549$ & $b=-1.415$ & $b=0.978$ \\
Granger-causa & 2 & $b=1.418$ & $b=1.856$ & $b=1.554$ \\
Crédito & $\cdots$ & $(0.000)$ & $(0.000)$ & $(0.000)$ \\
& 3 & $b=1.153$ & $b=1.459$ & $b=0.684$ \\
& & $(0.000)$ & $(0.000)$ & $(0.000)$ \\
\hline
\end{tabular}

Para estas regressões não foi possível intuir sobre nenhuma relação de causalidade relevante, a não ser para o PIB de Serviços, em que se observou causalidade bi-direcional entre o crédito rural e esta variável no modelo com uma defasagem. Dessa maneira, só se observou efeitos de externalidade do crédito rural para o produto do setor de serviços.

\subsection{Conclusões}

A relação entre sistema financeiro e crescimento econômico tem sido vastamente estudada tanto teórica como empiricamente. Uma das questões que a literatura relacionada ao tema procura responder trata do sentido da causalidade entre crédito e crescimento econômico. Em grande parte dos trabalhos que tiveram esta relação causal como foco, o resultado encontrado sugere o sentido da causalidade partindo do crédito para o crescimento [Rocha (2007), Marques Jr. e Porto Jr. (2004), Matos (2002)].

As premissas apresentadas por Levine (1997) justificam, sob o ponto de vista teórico, a tese de que o sistema financeiro induz o crescimento econômico. De acordo com tais premissas, o sistema financeiro garante maior eficiência na alocação dos recursos da economia, direcionando-os para os projetos mais rentáveis, incentivando a acumulação de capital, a inovação e, em última instância, o crescimento.

Partindo desta motivação teórica, este trabalho também teve como objetivo identificar o sentido da causalidade entre uma variável financeira e o crescimento econômico. Entretanto, optou-se por restringir esta análise ao crédito rural e verificar a validade da tese de que o 
sistema financeiro causa o crescimento econômico neste contexto específico, tendo em vista todas as peculiaridades apresentadas pelo crédito rural: maciça intervenção governamental no mercado de crédito, controles de quantidade e preço e concessão subsidiada. Buscou-se, então, verificar o sentido da causalidade entre crédito rural e PIB da agropecuária por meio de uma análise de Granger em painel para os municípios brasileiros no período 1999-2004.

Inicialmente, estimamos um modelo simplificado incluindo apenas as duas variáveis de interesse: crédito rural e PIB da agropecuária. Estes resultados preliminares forneceram evidências de Granger-causalidade unidirecional, partindo do PIB para o crédito.

Considerando que os efeitos espaciais são relevantes no contexto dos dados estudados, inserimos uma variável espacial, a exemplo do que fizeram Weinhold e Reis (1999). Os resultados obtidos nesta segunda parte da análise econométrica novamente suportam as evidências de Granger-causalidade unidirecional partindo da variável real (PIB da agropecuária) para a variável financeira (crédito rural).

Haja vista a disparidade regional verificada nas variáveis de produto agropecuário e crédito rural no Brasil, optamos por estimar os modelos de causalidade separadamente por região geográfica. Mais uma vez evidenciando esta disparidade, os resultados diferiram entre as regiões. Nas regiões Norte e Sudeste, observamos causalidade unidirecional partindo do PIB para o crédito em todas as defasagens consideradas. Nas regiões Nordeste e Centro-Oeste observamos causalidade bi-direcional nos modelos com uma defasagem e na região Sul os resultados sugerem a conclusão de que crédito rural Granger-causa PIB agropecuário. De certa maneira, o resultado encontrado para a região Sul concorda com o trabalho de Kroth, Dias e Giannini (2006), que apresentou a mesma análise, porém com dados municipais do Estado do Paraná.

Pelo fato de termos observado Granger causalidade partindo do crédito na região Sul do país, optamos por estimar regressões adicionais na tentativa de captar possíveis efeitos de externalidade do crédito rural para os produtos industrial, de serviços e total naquela região. Entretanto, os resultados das regressões não foram conclusivos em indicar nenhum efeito de causalidade relevante a não ser quanto ao PIB do setor de serviços para o qual foi possível observar Granger causalidade bi-direcional no modelo com uma defasagem. 
Em suma, os resultados encontrados não suportam a visão defendida por grande parte da literatura de que crédito causa crescimento e se desalinham com os resultados empíricos obtidos em trabalhos como Rocha (2007) e Matos (2002). Entretanto, há que se analisar este resultado com parcimônia sempre considerando o fato de que o instrumento financeiro sobre o qual este trabalho se debruçou apresenta determinadas peculiaridades que o tornam diferente dos outros tipos de crédito e talvez por esta razão os resultados não sejam semelhantes aos obtidos pelos trabalhos mencionados.

O fato de o crédito rural ser direcionado, tendo seus preços e quantidade ofertada controlados, pode estar fazendo com que o sistema financeiro não cumpra a sua função de selecionar clientes e direcionar recursos para os projetos mais rentáveis, favorecendo a inovação e o crescimento. Nessa situação, o crédito rural estaria apenas seguindo as áreas onde o PIB da agropecuária já é mais elevado ou já tem tendências de crescimento, em linha com o argumento de Robinson (1952): "where enterprise leads, finance follows". Nos termos de Marques Jr. e Porto Jr. (2004), o desenvolvimento financeiro estaria sendo dirigido pela demanda, ou uma decorrência do crescimento.

Sob este entendimento, a produção agropecuária seria guiada mais por sua expectativa de viabilidade econômica do que pela disponibilidade de crédito. Nesse contexto, mecanismos de redução da incerteza e risco, como antecipação de vendas, mercados futuros e mecanismos mais desenvolvidos de seguro seriam, possivelmente, mais relevantes que a própria disponibilidade de crédito para afetar a decisão de produção. A relevância destes mecanismos deve, entretanto, ser confirmada por trabalhos futuros complementares a este.

Por fim, a conclusão geral que se tira deste trabalho é que existe precedência temporal do PIB da agropecuária em relação ao crédito rural quando se analisam dados dos municípios brasileiros no período 1999 a 2004. 


\section{Referências Bibliográficas}

ALMEIDA, Eduardo S. e HADDAD, Eduardo A. "MEECA: um modelo econométrico espacial para projeção consistente de culturas agropecuárias". Rev. Econ. Sociol. Rural, Vol. 42, n. 3.2004

ANSELIN, Luc. "Local indicators of spatial association - LISA" Geographical Analysis, v. 27,n. 2, p.93-115, 1995.

ARELLANO, Manuel e BOND, Stephen. "Some tests of specification for panel data: Monte Carlo evidence and an application to employment equations." Review of Economic Studies. Vol. 58, pp. 337-341. 1991

ARESTIS, Philip e DEMETRIADES, Panicos. "Finance and growth: is Schumpeter right?" Análise Econômica, 6(30), pp. 5-21, 1998.

ASSUNÇÃO, Juliano J. e CHEIN, Flávia. "Condições de crédito no Brasil rural.” Revista de Economia e Sociologia Rural, Brasília, v.45, n 2, 2007.

BEARE, John B. "A monetarist model of regional business cycles". Journal of Regional Sciences. $\mathrm{n}^{\mathrm{o}}$. 16, pp.57-63, 1976.

BESLEY, Tim J. "How do market failures justify interventions in rural credit markets?" World Bank Research Observer vol. 9, n 1, pp. 27-47, 1994.

BURGUESS, Robin e PANDE, Rohine."Can rural Banks reduce poverty? Evidence from the Indian Social Banking Experiment" American Economic Review v. 95, n³, pp.780-95, 2005.

CARDOSO, Alessandra e ORTEGA, Antônio C. "Uma avaliação do PRONAF à luz da experiência européia de desenvolvimento rural, o programa leader" Anais do XXXVIII Encontro da SOBER.. 2000

CAVALCANTE, Luiz R. M. T. Sistema Financeiro no Brasil: aspectos regionais. In: XI Encontro Nacional de Economia Política, 2006, Vitória (ES). Anais, 2006

CHICK, Victoria e DOW, Sheila, C. "A Post-Keynesian perspective on the relation between banking and regional development." In: ARESTIS, Philip (Ed.) Post-Keynesian monetary economics. Aldershot: Edward Elgar, 1988.

COSTA, Ana Carla A., NAKANE, Márcio I. "Crédito Direcionado e Custo das Operações de Crédito Livre: uma Avaliação do Subsídio Cruzado do Crédito Imobiliário e Rural no Brasil." In: Relatório de Economia Bancária e Crédito. Banco Central do Brasil, 2005.

DEMETRIADES, Panicos e HUSSEIN, Khaled "Does financial development cause economic growth? Time series evidence from 16 countries". Journal of Development Economics, 51, pp.387-411, 1996. 
DOW, Sheila C. "The treatment of money in regional economics". In: DOW, S.C. money and the economic process. Aldershot: Elgar, 1987.

ENDERS, Walter. Applied econometric time series. New York: John Wiley \& Sons, 1995.

ENGLE, Robert F. e GRANGER, Clive W.J. "Cointegration and error-correction: representation, estimation, and testing." Econometrica. Vol. 55, pp.251-276, 1987.

FEIJÓ, Ricardo. Uma avaliação preliminar do PRONAF na produtividade da agricultura familiar. Textos para discussão - Série Economia. TD-E / 37 - 2003. Universidade de São Paulo, Faculdade de Administração, Economia e Contabilidade de Ribeirão Preto, 2003.

GOLDFAJN, Ilan, HENNINGS, Katherine e MORI, Helio. "Brazil's Financial System: Resilience to Shocks, no Currency Substitution but Struggling to Promote Growth". Banco Central do Brasil. Working Paper Series. N $^{\mathrm{O}} 75.2003$

GOLDSMITH, Raymond W. Financial Structure and Development. New Haven. Conn.: Yale University Press. 1969

GONZALES, Bernardo e COSTA, Sílvia. "Agricultura Brasileira: Modernização e Desempenho." Teoria e Evidência Econômica, Passo Fundo, UPF, v.5, n.10, p 5-35. 1998

GRANGER, Clive W.J. "Investigating Causal Relationships by Econometric Models and Cross-Spectral Methods." Econometrica. Vol. 37, N: 3, pp. 424-438.1969

GRANGER, Clive W.J. e HUANG, Ling-ling. "Evaluation of panel data models: Some suggestions from time-series.” Econometrica. Mimeo. U.C. San Diego. 1997

GREENWALD, Bruce C., LEVINSON, Alec e STIGLITZ, Joseph E. "Capital market imperfections and regional economic development." In: GIOVANNINI, Alberto (Ed.) Finance and development: Issues and experience. Cambridge: Center for Economic Policy Research - Cambridge University Press, 1993.

GRIGOROVSKI, Paulo Roberto E.et al. "O BNDES e a agroindústria nos anos 90” BNDES Setorial. No13, 2001.

GUILHOTO, Joaquim J. M. et al . "A importância do agronegócio familiar no Brasil”. Rev. Econ. Sociol. Rural, Brasília, v. 44, n. 3, 2006

HOLTZ-EAKIN, Douglas, NEWEY, Whitney e ROSEN, Harvey, S. "Estimating Vector Autoregressions with Panel Data". Econometrica. Vol.56, pp.1371-1395. 1988

HSIAO, Cheng. Analysis of Panel Data. New Jersey: Prentice-Hall, Inc. 1993

KHANDKER, Shahidur R. 2005. "Microfinance and Poverty: Evidence Using Panel Data from Bangladesh,” World Bank Economic Review. Vol. 19, No. 3. 1998.

KING, Robert e LEVINE, Ross. "Finance and Growth: Schumpeter might be right".The Quarterly Journal of Economics. Vol.108, pp.717-739.1993 
KING, Robert e LEVINE, Ross. "Financial Development and Economic Development." In: Capital Markets and Financial Intermediation. Mayer, C. e Vives, X. (eds.) Cambridge: Cambridge University Press. 1993

KLEIN, Brigitte; MEYER, Richard et al. "Better Practices in Agricultural Lending". Agricultural Finance Revisited, No 3. Rome, Food and Agricultural Organisation of the UN (FAO), Deutsche Gesellschaft für Technische Zusammenarbeit (GTZ). 1999

KROTH, Darlan e DIAS, Joilson "A Contribuição do Crédito Bancário e do Capital Humano no Crescimento Econômico dos Municípios Brasileiros: Uma Avaliação em Painéis de Dados" Anais do XXXIV Encontro Nacional de Economia , ANPEC, 2006.

KROTH, Darlan; DIAS, Joilson e GIANNINI, Fábio. "A importância do crédito rural e da educação na determinação do produto per capita rural: um estudo dinâmico em painéis de dados para os municípios paranaenses." In: XLIV Congresso da Sociedade Brasileira de Economia e Sociologia Rural, Fortaleza-CE, 2006.

KUMAR, Anjali. Acess to Financial Services in Brazil. The World Bank, 2005.

LA PORTA, R., F. LOPEZ-DE-SILANES, A. SHLEIFER, 2002. "Government ownership of banks." Journal of Finance 57, 265-301.

LEVINE, Ross e ZERVOS, S. "Stock markets, banks, and economic growth." The American Economic Review, 88(3), pp.537-558, 1998.

LEVINE, Ross. "Financial development and economic growth: views and agenda." Journal of Economic Literature, XXXV, pp.688-726, 1997

LUCAS, Robert. "On the mechanism of economic development". Journal of Monetary Economics. Vol.22. pp.3-42, 1988

MACKINNON, J.G. "Critical Values for Cointegration Tests." In: Engle, R. F. e Granger, C.W.J (Ed.). Long-run Economic Relationships: Readings in Cointegration, Oxford: Oxford University Press, 1991.

MAGALHÃES, André Matos et al. "The family farm program in Brazil: the case of Pernambuco”. XVIII Congresso SOBER. Ribeirão Preto, SP. 2005

MARQUES JR., Túlio e PORTO JR., Sabino. "Desenvolvimento financeiro e Crescimento Econômico no Brasil - Uma avaliação econométrica." PPGE/UFRGS. Trabalho para Discussão $\mathrm{N}^{\mathrm{o}}:$ 11, 2004.

MATOS, Orlando C. "Desenvolvimento do Sistema Financeiro e Crescimento Econômico no Brasil: Evidência de Causalidade." Banco Central do Brasil. Trabalho para Discussão No: 49.2002

MEYER, Richard. "Iniciativas asiáticas para desenvolver mercados financeiros rurais: Algumas idéias para o Brasil.”In: Seminário Internacional BNDES Microfinanças. Rio de Janeiro: BNDES. 2000 
MICCO, Alejandro J. e PANIZZA, Ugo. "¿Debe participar el gobierno en el sector bancário?" In: Progreso Económico y Social en América Latina. Banco Interamericano de Desenvolvimento (eds.), Cap.11, 2005.

PIRES, M. C. C. Crédito e crescimento econômico: evidências para os municípios brasileiros. Anais do VIII Encontro de Economia da Região Sul-ANPEC-SUL, Porto Alegre-RS, 2005.

RAJAN, Raghuram G., ZINGALES, Luigi. Financial Dependence and Growth. NBER Working Paper n. 5554,1998.

REICHSTUL, Daniel; LIMA, Gilberto T. "Causalidade entre crédito bancário e nível de atividade econômica na região metropolitana de São Paulo: algumas evidências empíricas". Estudos Econômicos, São Paulo, v. 36, n. 4, 2006.

RIGOTTI, José Irineu R., VASCONCELLOS, Idamila. R. "Uma análise espacial exploratória dos fluxos populacionais brasileiros nos períodos 1986-1991 e 1995-2000”. In: IV Encontro Nacional sobre Migrações, 2005, Rio de Janeiro. Anais do IV Encontro Nacional sobre Migrações. p. 1-20.2005.

ROBINSON, J. "The generalization of the General Theory." In: The rate of interest and other essays. London: MacMillan, 1952.

ROCHA. Bruno P. Ensaios sobre economia bancária e política monetária no Brasil em uma abordagem regionalizada. Tese (Doutorado). IPE/FEA/USP. São Paulo, 2007.

ROMER, Paul. "Increasing Returns and long-run growth". Journal of Political Economy. Vol. 94, pp.1002-1037, 1986

SANT'ANNA, André A. e FERREIRA, Francisco Marcelo R. "Crédito Rural: da especulação à produção" Boletim Visão do Desenvolvimento. $\mathrm{n}^{\circ}$ 11, 2006

SCHUMPETER, Josef A. "The theory of economic development." Cambridge: Harvard University Press, 1959 (Edição Original: 1912).

SOLOW, Robert "A contribution to the theory of economic growth." Quarterly Journal of Economics. Vol. 70, pp. 65-74, 1956.

STIGLITZ, Joseph E. e WEISS, Andrew "Credit rationing with imperfect information." American Economic Review. Vol. 71, pp. 393-410. 1981.

WEDEKIN, Ivan. "A política agrícola em perspectiva" Revista de Política Agrícola. Ano XIV, Edição Especial. 2005

WEINHOLD, Diana e REIS, Eustáquio. "Model of evaluation and causality testing in short panels: The case of infrastructure provision and population growth on Brazilian Amazon." Journal of Regional Science, Vol.41, No. 4, pp. 639-658. 2001.

WOOLDRIDGE, Jeffrey M. Econometrics Analysis of Cross-Section and Panel Data. Cambridge, MA: The MIT Press. 2002 
ZARA, Thais M. Desenvolvimento Financeiro, Crescimento e Desigualdade nos Estados Brasileiros. Dissertação (Mestrado). IPE/FEA/USP. São Paulo. 2006 


\section{ANEXO}

\section{QUADRO 1}

\section{Sumário das Principais Referências Bibliográficas}

\section{Autores Amostra \\ Relação entre Sistema \\ Financeiro e Crescimento Econômico \\ Evidências de causalidade}

Valores iniciais de

desenvolvimento financeiro

formam uma boa previsão para

valores subseqüentes de

crescimento econômico

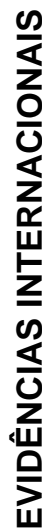

King \& Levine (1993)

diferentes graus

de

indicadores utilizados

desenvolvimento

Maior proporção de bancos públicos

Dados de bancos governamentais

Lopez-de-

Silanes e

Shleifer (2002) está associada a menor

desenvolvimento financeiro e menor crescimento da renda per capita e produtividade
Levine e
42 países entre
Zervos (1998)
no mercado acionário são variáveis
relevantes para explicar o crescimento econômico.

Desenvolvimento bancário e liquidez

\section{Demetriades e \\ Hussein}

(1996)

16 países em desenvolvimento

Os resultados empíricos não suportam a visão de que é o sistema financeiro o condutor do crescimento econômico.

Evidências de causalidade bidirecional entre desenvolvimento financeiro e crescimento econômico.

\begin{tabular}{ccc}
\hline Rajan e & Dados micro- & O nível de desenvolvimento financeiro \\
Zingales & econômicos do & setor industrial de \\
(1996) & $\begin{array}{c}\text { se mede pela sua capacidade de } \\
\text { finersonciar a inovação. }\end{array}$
\end{tabular}

Justificativa teórica para a causalidade: sistema financeiro financia a inovação que por sua vez é causa do crescimento

\section{Séries brasileiras} nos períodos 1947-2000, 1963-

O desenvolvimento financeiro exerce efeito positivo sobre o crescimento da economia brasileira, sem 2000, 1970-2000 retroalimentação.

\begin{tabular}{|c|c|}
\hline $\begin{array}{l}\text { Marques Jr. e } \\
\text { Porto Jr. } \\
\text { (2004) }\end{array}$ & $\begin{array}{c}\text { Séries temporais } \\
\text { brasileiras no } \\
\text { período } 1950- \\
2000\end{array}$ \\
\hline
\end{tabular}

A contribuição do sistema financeiro para o crescimento depende da escala operacional deste sistema, uma vez que a escala é determinante para diminuir os custos de transação.

Impactos diretos e unidirecionais do desenvolvimento financeiro para o crescimento econômico.

Relação de causalidade inequívoca, partindo do sistema financeiro para o crescimento econômico quando se utilizam indicadores do sistema bancário

1) Utilizando dados anuais, os indicadores financeiros Grangercausam os indicadores de crescimento; 2) Utilizando dados mensais os resultados de causalidade são inconclusivos associando sistema bancário e nível de produto.

$\begin{array}{cc}\text { Kroth e Dias } & \text { Dados municipais } \\ (2006) & \text { no período 1999- } \\ 2003\end{array}$

Disponibilidade de crédito associada ao capital humano gera efeitos positivos sobre o crescimento econômico.
Evidências de causalidade partindo das variáveis financeiras para o crescimento econômico. 